\title{
Evaluation of teaching practicum for pre-service English language teachers: A scale development study
}

\author{
İlknur Kazaz ${ }^{\mathrm{a} 1}$ iD , Nuray Alagözlü b ì \\ ${ }^{a}$ Karaeniz Technical University, Trabzon, Turkey \\ Hacettepe University, Ankara, Turkey
}

APA Citation:

Kazaz, İ.,\& Alagözlü, N. (2020). Evaluation of Teaching Practicum for pre-service English language teachers: A scale development study. Journal of Language and Linguistic Studies, 16(3), 1562-1593.

Submission Date: 19/05/2020

Acceptance Date:29/07/2020

\begin{abstract}
The aim of this study is to develop a measurement tool that evaluates the teaching practicum to shed light on the expectations and attitudes of English teacher candidates in relation to teaching practicum. In this context, two measurement tools; expectation scale and reaction scale were prepared based on the amalgamation of Kirkpatrick Training Evaluation Theory (2000) and EPOSTL(2007). This study was conducted to have an overall critical analysis of the current practicum program applied in Turkey to determine the pre-service teachers' views about the existing face to face teaching practicum model and what could be done to make up for the deficits in the current implementation. Within the scope of the study, validity and reliability studies were conducted. For research validity; a pilot study was conducted at a state university with senior level ELT students at 2018-2019 spring academic year. As a result of the pilot study item writing and item pooling stages were completed. Expert opinion was received from three academicians from the field in order not to assess the face validity, content validity and construct validity. Exploratory Factor Analysis (EFA) and Confirmatory Factor Analysis (CFA) were conducted with 294 senior level ELT students who were taking the School Experience course at 2019-2020 fall term around various universities in Turkey. Working groups were determined based on maximum diversity sampling method. Cronbach's alpha coefficients were calculated as .96 and .98 for the expectation and reaction scales respectively. In line with the applications and analyzes, it can be said that the scales are valid, reliable and they have sufficient values in terms of psychometry.
\end{abstract}

(C) 2020 JLLS and the Authors - Published by JLLS.

Keywords: teaching practicum; pre-service teacher training; program evaluation; scale development.

\section{Introduction}

Pre-service teacher training, preparation and development has a prominent place in the list of government's educational agenda and is prioritized with the aim of inducing a qualified instruction in Turkish schools, and training teachers within the country. Teaching practicum is an educational activity which involves pre-service teachers, cooperating teachers, university supervisors, administrators, and

\footnotetext{
1 Corresponding author. Tel.: +90-462-377-3690
}

E-mail address: ilknurkazaz@ktu.edu.tr 
students. Due to its nature, it entails many different considerations such as lesson plans, observation reports, reflective practice, visits of university supervisors, etc. During the teaching practicum, preservice teachers basically benefit from lesson observation, the cooperating teacher and practicum school, university supervisors' supervision, communication with other school members, and the peer teachers (Gan, 2014). Pre-service teachers who are taking initial teacher training need to develop several competencies to guarantee their preparation to teach. Pre-service teachers should demonstrate their ability in writing lesson plans, in progression of subjects, meeting the needs of the students, administering a variety of teaching strategies and methods, presenting the content with an exploratory, vivid language and showing the ability to use digital sources. Therefore, teaching practicum is an important program that amalgamates theory and practice in teacher training. In this study, the "School Experience" course included in the curricula of ELT Programs is evaluated based on 4th grade students' opinions. Thus, the aim of this study is to investigate the problems that the pre-service English teachers encounter in practicum process and find out how these problems affect the pre-service teachers. This study is of significance, because it addresses the impact of such an important program upon pre-service teachers' acquisition of teaching qualifications and the problems encountered in practice. Through this evaluation, for the improvement of the Practicum nationwide and a theoretical framework, an interactional model which has higher accountability and snatches the requisites of the era is proposed for the use of the Ministry of Education.

\subsection{Literature Review}

There is considerable amount of studies that indicate the value of practicum in the professional development of Pre-service teachers. One of the advantages of this period is that, it supports socialization within the profession and develops teaching skills (Hascher et al., 2004). Teaching practicum provides the pre-service teachers with opportunities to practice and develop the knowledge and experiences gained through 4 year-long professional university education via authentic teaching and learning practice. The practice-teaching period provides pre-service teachers with the opportunity to apply the knowledge and skills they have acquired and be evaluated at the same time have been taught (Duffy, 2005). When the studies carried out within the scope of teaching practice are examined, it is seen that there are studies conducted to examine the experiences, opinions and expectations of prospective teachers, mentor teachers, and university supervisors (Hudson, 2009 ; Ronfeldt and Reinninger, 2012; Zeichner, 2002). These studies underline that the guidance of mentor teachers and university lecturers has a significant impact on the experience of candidates in this process (Cook, 2007; Smagorinsky et al., 2006). In Turkish context, while a measurement tool was developed by Çevik and Alat (2012) to determine the attitudes of the practice teachers, the "Practice Teacher Proficiency Scale" developed by Kiraz (2003) was developed to determine to what extent the practice teachers fulfilled the expectations of the candidates. On the other side of the coin, when the teacher candidates are faced with problems during the process, this can have long-term damages on their future profession as well, which in turn brings forward the need to enlighten the problems in the program and solve them on a professional basis. Mentors' knowledge on how teaching practice should be is found insufficient in Boz and Boz 2006 study and there is a gap between theoretical knowledge that are taught at universities and real courses in the schools (Seferoğlu, 2006). The realities of the workplace frequently make novice teachers suffer from the gap between the theory and the practice. Teacher candidates can be said to go through experiential learning through this process. It is based on Kolb's (1984) model of experiential learning; the concrete experience, reflective observation of that experience, abstract conceptualization including learning from the experience, active experimentation and testing of the new concepts. The rules for teaching practicum program is mentioned in Faculty-School Cooperation manual. During the internship of pre-service teachers, there is a bilateral process in which both parties benefit from each 
other. In the directive published by the Ministry of Education the duties of all the stakeholders are defined clearly. However the Faculty-School Cooperation Manual has not been updated since 1998. There is a need for the revision of the manual. For a sound theoretical evaluation this study is based on two theories a) Kirkpatrick's Four Levels of Training Evaluation b) EPOSTL. Assessing the effectiveness of the training entails the utilization of the Kirkpatrick's Four-Level Training Evaluation Model developed by Donald Kirkpatrick (2000). The model is highly adaptive and adds up to the traditional training models. The results of using the model are positive both for teachers and the learners. These four levels include learning, behavior, results and reaction.

a- Reaction: Individuals' reactions to the learning experiences

b- Learning: Individuals' acquisition of important information, knowledge, skills, and attitudes

c- Transfer: Changes in behavior in an authentic setting due to the training program

d- Results: The effect/impact that the newly acquired behaviors have on the people and the organization

The second theory underlying this scale development study is EPOSTL (2007). It is a document that addresses the content of teacher education and core competences. It formulates didactic competence descriptors (I can...) related to language teaching, helps assess and monitor those competences, record them and maintains links between CEFR and English Language Portfolio (ELP). The main aim is to encourage students to reflect on the competences of a teacher, to help prepare them for their future profession in a variety of teaching contexts, to promote discussion between them and their peers, teacher educators and mentors, to facilitate self-assessment of them to provide an instrument which helps chart progress. As a result, it increases transparency of education programs, encourage a reflective mode in teacher education and aids comparison of teacher education programs (Newby, 2007).

\subsection{Research Questions}

1- What are the expectations of pre-service EFL teachers from Teaching Practicum?

2- What are the reactions of pre-service EFL teachers to the Teaching Practicum?

\subsection{Scale Development}

This research is a scale development study. In this context, it is aimed to develop a valid and reliable scale that evaluates face to face teaching practicum. In this section, the scale development process is explained in detail.

\subsection{Pilot Study}

For the pilot study the researcher conducted a student questionnaire for the teacher candidates and focus group interview with mentor teachers and a written questionnaire with the administrators. Piloting was made with senior ELT students in the 2018-2019 academic year. The items in the study were based on EPOSTL and Kirkpatrick Training Evaluation model and covered the expectations from the practicum program. The questionnaire included a qualitative part in which the students declared their positive and negative experiences in the first part. In the second part they answered five questions to answer what might motivate them for their future profession. The replies given to the questions by the teacher candidates were categorized by the researcher at the end of the study.

The students were found to have self- expectations and job-related expectations. And their expectations were either positive or negative. This gave the researcher ideas for item writing. 
In order to facilitate the indicators, a group of mentor teachers were asked questions in a group work. The researcher conducted a focus-group interview with the mentor teachers with two mentor teachers at an Anatolian High School. The answers to the questions were transcribed and analyzed with a thematic analysis. At the end of the interview with the teachers the researcher found that the teachers also wanted some changes in the practicum. They had teacher candidate related, job-related, university related issues and mentioned about their problems and desires. The researcher also conducted a written questionnaire with the administrators as well. The administrators also had teacher candidate related, university related, mentor teachers related and formal procedures related wishes.

\section{Method}

In the scale development process, firstly the literature was examined and the theories and contents related to the concept of teaching practicum were investigated. Then, Kirkpatrick Training Evaluation (2000) and EPOSTL(2007) theories that dominate teaching practicum literature are identified. As a result of literature review, a pilot study was initiated with $4^{\text {th }}$ grade pre-service teachers at a state university. After the pilot study, the scale questions were formed. Then the scales were administered to the study group. Quantitative research design was chosen for this study.

\subsection{Sample/Participants}

In this research, the study group for EFA/CFA consists of 294 senior level English Language Teaching program pre-service teachers from all around Turkey; Erzurum province Atatürk University, İstanbul province Yıldız Teknik University, Gaziantep province Gaziantep University, Çanakkale province 18 Mart University, Denizli province Pamukkale University, Ankara province Gazi University in order to see the regional tendencies as well. In order not to disrupt the power relationship the researcher didn't administer the scale in her own affiliation. Approximately 300 participant number is a good number of participant as stated by Tinsley and Tinsley (1987) and Comrey (1973) as cited in DeVellis (2017). Exploratory and Confirmatory factor analysis was made for the reliability and validity of both the expectation scale and the reaction scales separately. The data were obtained from the students' responses to the scale via IBM Statistical Package for Social Sciences (SPSS) 24v and AMOS 19. Exploratory and Confirmatory factor analysis was made within each sub-division itself. CMIN, RMSEA and CFI values were analyzed. In this context, it is aimed to reach maximum diversity by reaching teachers with different demographic characteristics (gender, age, etc.). Descriptive statistics for the CFA study group are given in Table 3.

\subsection{Instruments}

Expectation and Reaction scale was formed for the specific study. Exploratory and Confirmatory factor analysis was made for the reliability and validity of both the expectation scale and the reaction scales separately. The data were obtained from the students' responses to the scale via IBM Statistical Package for Social Sciences (SPSS) 24v and AMOS 19. Exploratory and Confirmatory factor analysis was made within each sub-division itself. CMIN, RMSEA and CFI values were analyzed. In this context, it is aimed to reach maximum diversity by reaching teachers with different demographic characteristics (gender, age, etc.). Descriptive statistics for the CFA study group are given in Table 3. 


\subsection{Data Collection Procedures}

At this stage, the answers to the questionnaires in the pilot study were scanned to create the item pool, and the measurement tools within the scope of expectations from and reactions to the teaching practicum were determined. Then, the items in the measurement tools were developed. The items in the item pool were created by making use of the literature. Item pooling was made based on EPOSTL and Kirkpatrick Training Evaluation Model. In this way, 83 items were written for the expectation scale and 44 items were written for the reaction scale. The scales were prepared as a five-grade Likert type. The draft scales were presented to the opinion of three field experts in terms of content and scope. One of the experts was a professor at a state university in the field of teacher education policy, assessment and evaluation, one of them was an Assistant Professor at a private university in the field of teacher training, and the other one was an Assistant Professor at a state university in the field of educational statistics. After the scale items were revised, small changes were made in line with expert opinions, they were edited and ready-to-use forms were obtained. As a result, 7 items were corrected in the expectation scale and two more items were added and 8 items were corrected in the reaction scale. The items that were found by the experts as ambiguous, unclear or containing more than one meaning were excluded from the scale. The Likert-type scales were arranged as strongly disagree(1), disagree (2), neutral(3), agree (4) and strongly agree (5). After informing the prospective teachers in the research group about the study, the applications were made in a suitable timeframe determined outside the class hours. Data collection was carried out in print by the researcher. The collected data was primarily transferred to the IBM SPSS $24 \mathrm{v}$ program. Then, the data were analyzed within the scope of validity and reliability studies.

\section{Results}

The scales were administered to 294 participants from all around Turkey.

Table 1. Descriptives for the participants

\begin{tabular}{cccccccccc}
\hline students & N & PAU & YTU & Gazi Uni. & OMU & Gaziantep Uni. & Ataturk Uni. & M & F \\
\hline & 294 & 66 & 37 & 60 & 48 & 37 & 46 & 85 & 209 \\
\hline
\end{tabular}

Table 2. Descriptives for the age range

\begin{tabular}{lcccccc}
\hline students & N & Mean & Std. Dev. & Median & Min & Max \\
\hline & 294 & 22.33 & 1.97 & 22 & 20 & 39
\end{tabular}

Exploratory factor analysis was performed within the scope of the validity studies of the scale. In this context, Kaiser - Meyer - Olkin (KMO) value and Bartlett Sphericity Test were performed. When the literature is examined, it is stated that .50 or .60 value is base value for KMO. For example, Kaiser (1974) states that KMO value greater than .50 may be sufficient to perform factor analysis. The Bartlett's Sphericity test is a statistical technique used to check whether research data come from a multivariate normal distribution. Thus, that chi-square test statistic is significant indicates that the data comes from a normal multivariate distribution. 
Factors with eigenvalues greater than 1 were taken into consideration in the evaluation of the findings obtained . In addition, within the scope of exploratory factor analysis, items with a factor load value below .30 were removed from the scale form. When Exploratory Factor Analysis was performed based on varimax rotation, it was observed that some items did not load any factors, some items loaded more than one factor, and some load values were below .40 and these items were removed from the scale and EFA was repeated. Varimax rotation method was used to determine the factor structure of the developed scale.

\subsection{Expectation Scale Factor Analysis}

Exploratory Factor Analysis about the University Supervisors Items

The expectation scale had 24 items covering the expectations of participants in relation to the university supervisors. The items were mainly about receiving information before the practicum from the supervisors about the content, scope, evaluation and schedule. It also included factors about receiving feedback and support from the supervisor. As a result of the factor analysis three expectation statements had to be eliminated from the scale S9, S22, and S23. These items were about receiving guidance from the supervisor about the necessary teaching principles and techniques for the course firstly. Secondly they also included expectation from the supervisor to be objective and patient. It is evident that the pre-service teachers do not want their supervisors to interfere in their own teaching methods in order find their own ways and accept that supervisors cannot be objective or too patient throughout the process.

Table 3. Expectation Scale Factor Analysis Results about the University Supervisors Items

\begin{tabular}{cccc}
\hline & \multicolumn{3}{c}{ Rotated Factors } \\
\cline { 2 - 4 } S16 & 0.816 & & \\
S14 & 0.812 & & \\
S15 & 0.803 & & \\
S13 & 0.790 & & \\
S12 & 0.775 & & \\
S17 & 0.753 & & \\
S11 & 0.748 & & \\
S20 & 0.701 & & \\
S19 & 0.689 & & \\
S21 & 0.687 & & \\
S18 & 0.679 & & \\
S10 & 0.666 & & \\
S3 & & 0.825 & \\
S2 & & 0.823 & \\
S4 & & 0.822 & \\
S1 & & 0.780 & \\
S5 & & 0.757 & \\
S6 & & 0.606 & \\
S8 & & & 0.779 \\
S24 & & & 0.751 \\
S7 & & & \\
\hline
\end{tabular}




\begin{tabular}{cccc}
\hline Eigenvalues & 12.839 & 1.676 & 1.164 \\
VAO & 36.206 & 23.870 & 14.585 \\
KVAO & 36.206 & 60.076 & 74.661 \\
\hline MO-MSA $=0.948$, Bartlett Chi-Square $=3886.232, \mathrm{p}<0.001$
\end{tabular}

In factor analysis made by removing S9, S22 and S23 statements, the expectation scale includes a sufficiently effective scale structure that measures the expectations of university teachers (KMO-MSA $=0.948)$. This value reflects an excellent scale structure. According to the Bartlett test, there are significant correlation levels between the items that reflect a certain structure and the scale is a scale with at least two sub-dimensions ( $\mathrm{p}<0.001$ ). A total of 3 factors with eigenvalue greater than 1 were obtained. Factor 1 explains $36.206 \%$ of total variance, factor $223.870 \%$ and factor 3 explains $14.5885 \%$, while these three factors together explain $74.661 \%$ of total variance. There are 12 items under factor 1 , 6 items under factor 2 and 3 items under factor 3. F1 factor consists of S16, S14, S15, S13, S12, S17, S11, S20, S19, S21, S18 and S10 items according to factor loads, respectively. The F2 factor consists of S3, S2, S4, S1, S5 and S6 items, respectively, according to factor loads. F3 factor consists of S8, S24 and $\mathrm{S} 7$ items, respectively, according to factor loads.

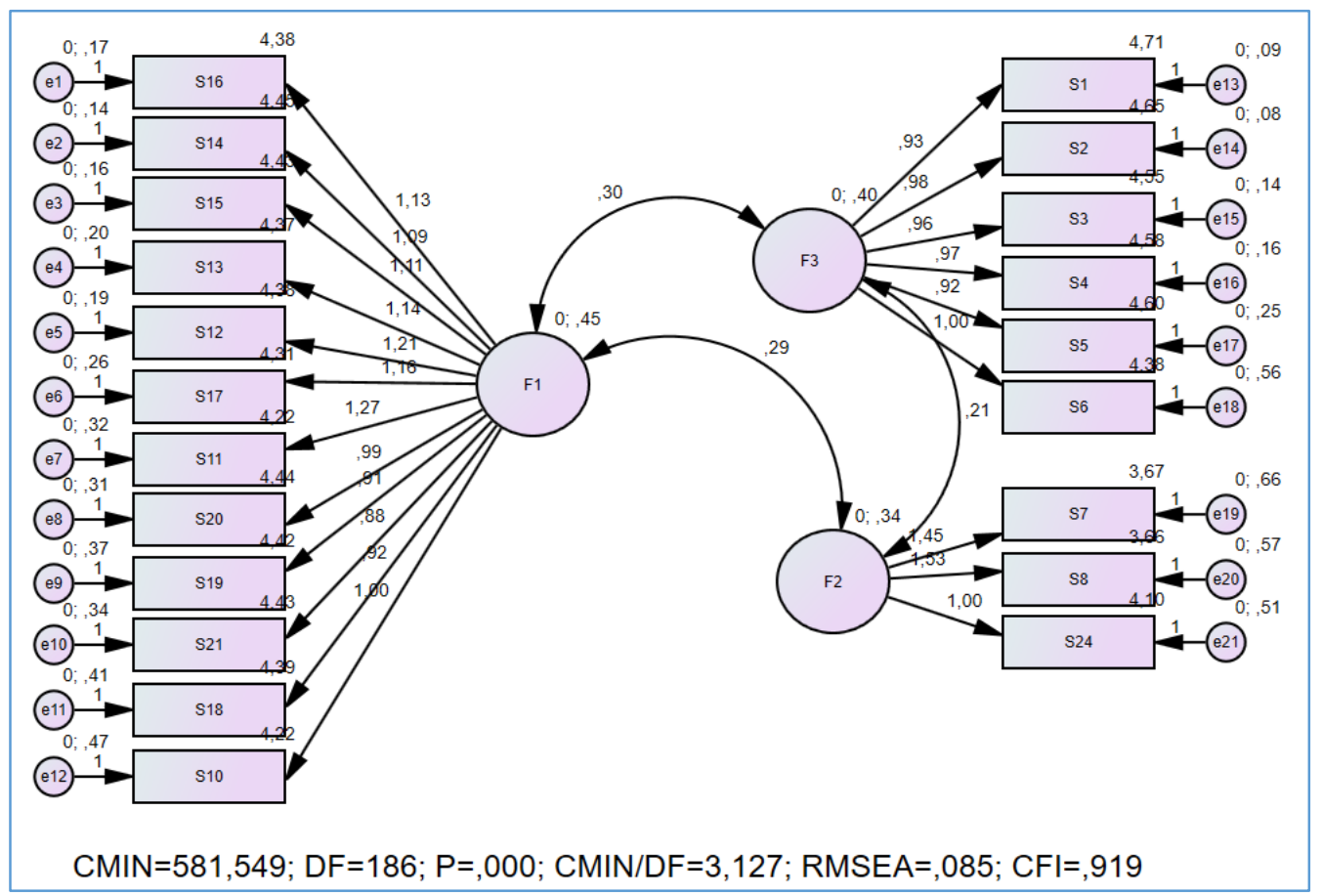

Figure 1. Confirmatory factor analysis non-standard path coefficients

Table 4. Confirmatory Factor Analysis Results

\begin{tabular}{|c|c|c|c|c|c|c|c|}
\hline & & & B1 & B2 & Std. Error & Test Statistics & $\mathrm{p}$ \\
\hline S16 & $<--$ & $\mathrm{F} 1$ & 0.877 & 1.132 & 0.079 & 14.267 & $<0.001$ \\
\hline S14 & $<--$ & $\mathrm{F} 1$ & 0.886 & 1.090 & 0.076 & 14.406 & $<0.001$ \\
\hline S13 & $<---$ & $\mathrm{F} 1$ & 0.864 & 1.143 & 0.081 & 14.082 & $<0.001$ \\
\hline $\mathrm{S} 12$ & $<---$ & $\mathrm{F} 1$ & 0.878 & 1.210 & 0.085 & 14.297 & $<0.001$ \\
\hline S17 & $<--$ & $\mathrm{F} 1$ & 0.832 & 1.156 & 0.085 & 13.575 & $<0.001$ \\
\hline S11 & $<---$ & $\mathrm{F} 1$ & 0.833 & 1.269 & 0.093 & 13.612 & $<0.001$ \\
\hline
\end{tabular}




\begin{tabular}{lccccccc} 
S20 & $<---$ & F1 & 0.763 & 0.989 & 0.079 & 12.485 & $<0.001$ \\
S19 & $<--$ & F1 & 0.709 & 0.910 & 0.078 & 11.617 & $<0.001$ \\
S18 & $<---$ & F1 & 0.690 & 0.918 & 0.081 & 11.349 & $<0.001$ \\
S21 & $<---$ & F1 & 0.710 & 0.876 & 0.075 & 11.674 & $<0.001$ \\
S15 & $<---$ & F1 & 0.880 & 1.111 & 0.082 & 13.567 & $<0.001$ \\
S10 & $<--$ & F1 & 0.697 & 1 & & & \\
S7 & $<---$ & F2 & 0.721 & 1.452 & 0.158 & 9.212 & $<0.001$ \\
S8 & $<---$ & F2 & 0.763 & 1.530 & 0.162 & 9.455 & $<0.001$ \\
S24 & $<---$ & F2 & 0.630 & 1 & & & \\
S1 & $<--$ & F3 & 0.893 & 0.926 & 0.073 & 12.723 & $<0.001$ \\
S2 & $<---$ & F3 & 0.911 & 0.982 & 0.076 & 12.888 & $<0.001$ \\
S3 & $<---$ & F3 & 0.850 & 0.963 & 0.078 & 12.271 & $<0.001$ \\
S4 & $<---$ & F3 & 0.834 & 0.967 & 0.080 & 12.097 & $<0.001$ \\
S5 & $<---$ & F3 & 0.760 & 0.923 & 0.082 & 11.239 & $<0.001$ \\
S6 & $<---$ & F3 & 0.643 & 1 & & & \\
\hline
\end{tabular}

As a result of the confirmatory factor analysis, the path coefficients of the items under each factor were found to be statistically significant. Model fit coefficients are within the desired limits and the results are presented in Figure 1.

\section{Exploratory Factor Analysis about the Mentor Teachers Items}

The expectation scale had 33 items covering the expectations of participants in relation to the mentor teachers. The items were mainly about being introduced to the other teachers and students and receiving information about the environment from the mentor teacher. It also included receiving help throughout the lesson planning, necessary lesson techniques, feedback and encouragement.

As a result of the factor analysis statements $\mathrm{S} 33, \mathrm{~S} 36, \mathrm{~S} 37, \mathrm{~S} 38, \mathrm{~S} 39$ and S48 were eliminated were from the scale. These items asked the participants whether they wanted to be checked by the mentor teachers regarding the course materials, lesson plans or class management. Similar to the expectations from the supervisors, the teacher candidates still want freedom in their own teaching strategies so they reject being checked and do not believe in constructive criticism. So this arouses in mind that they have a prejudice against mentor teachers and are afraid of being criticized harshly.

Table 5. Expectation Scale Factor Analysis Results about the Mentor Teachers Items

\begin{tabular}{lccccc}
\hline & \multicolumn{5}{c}{ Rotated Factors } \\
\cline { 2 - 5 } & 1 & 2 & 3 & 4 & 5 \\
\hline S44 & 0.851 & & & & \\
S41 & 0.849 & & & & \\
S43 & 0.836 & & & & \\
S46 & 0.817 & & & & \\
S40 & 0.774 & & & & \\
S42 & 0.753 & & & & \\
S49 & 0.746 & & & & \\
\hline
\end{tabular}




\begin{tabular}{|c|c|c|c|c|c|}
\hline S35 & 0.466 & & & & \\
\hline $\mathrm{S} 32$ & & 0.698 & & & \\
\hline S26 & & 0.656 & & & \\
\hline $\mathrm{S} 28$ & & 0.643 & & & \\
\hline S56 & & 0.632 & & & \\
\hline S34 & & 0.578 & & & \\
\hline S31 & & 0.565 & & & \\
\hline S27 & & & 0.764 & & \\
\hline S30 & & & 0.656 & & \\
\hline S29 & & & 0.628 & & \\
\hline S25 & & & 0.624 & & \\
\hline S54 & & & & 0.749 & \\
\hline S55 & & & & 0.728 & \\
\hline S53 & & & & 0.605 & \\
\hline S57 & & & & 0.496 & \\
\hline S47 & & & & & 0.788 \\
\hline S51 & & & & & 0.773 \\
\hline S50 & & & & & 0.647 \\
\hline S52 & & & & & 0.644 \\
\hline Eigenvalues & 11.656 & 2.447 & 1.754 & 1.231 & 1.104 \\
\hline VAO & 22.747 & 12669 & 11.389 & 10.354 & 10.222 \\
\hline KVAO & 22.747 & 35.416 & 46.805 & 57.159 & 67.379 \\
\hline
\end{tabular}

In the factor analysis made with the remaining 27 statements by removing S33, S36, S37, S38, S39 and S48 items, the expectation scale has a sufficiently effective scale structure to measure the expectations in relation to mentor teachers $(\mathrm{KMO}-\mathrm{MSA}=0.914)$. This value reflects an excellent scale structure. According to the Bartlett test, there are significant correlation levels between the items that reflect a certain structure, and the scale is the bit scale with two sub-dimensions ( $\mathrm{p}<0.001$ ). As a result of the factor analysis process, a total of 5 factors with eigenvalues greater than 1 were obtained. Factor 1 explains $22.747 \%$ of total variance, factor 2 explains $12.669 \%$, factor $311.389 \%$, factor $410.354 \%$ and factor $510.22 \%$, while these five factors explain $67.379 \%$ of the total variance together.

There are 9 items under factor 1, 6 items under factor 2, and 4 items under factor 3, factor 4 and factor 5. F1 factor is formed in S44, S41, S45, S43, S46, S40, S42, Q49 and S35 items according to factor loads, respectively. The F2 factor consists of S32, S26, S28, S56, S34 and S31 items, respectively, according to factor loads. The F3 factor consists of S27, S30, S29 and S25 items, respectively, according to factor loads. The F4 factor consists of S54, S55, S53 and S57 items, respectively, according to factor loads. F5 factor consists of S47, S50, S51 and S52 items, respectively, according to factor loads. 


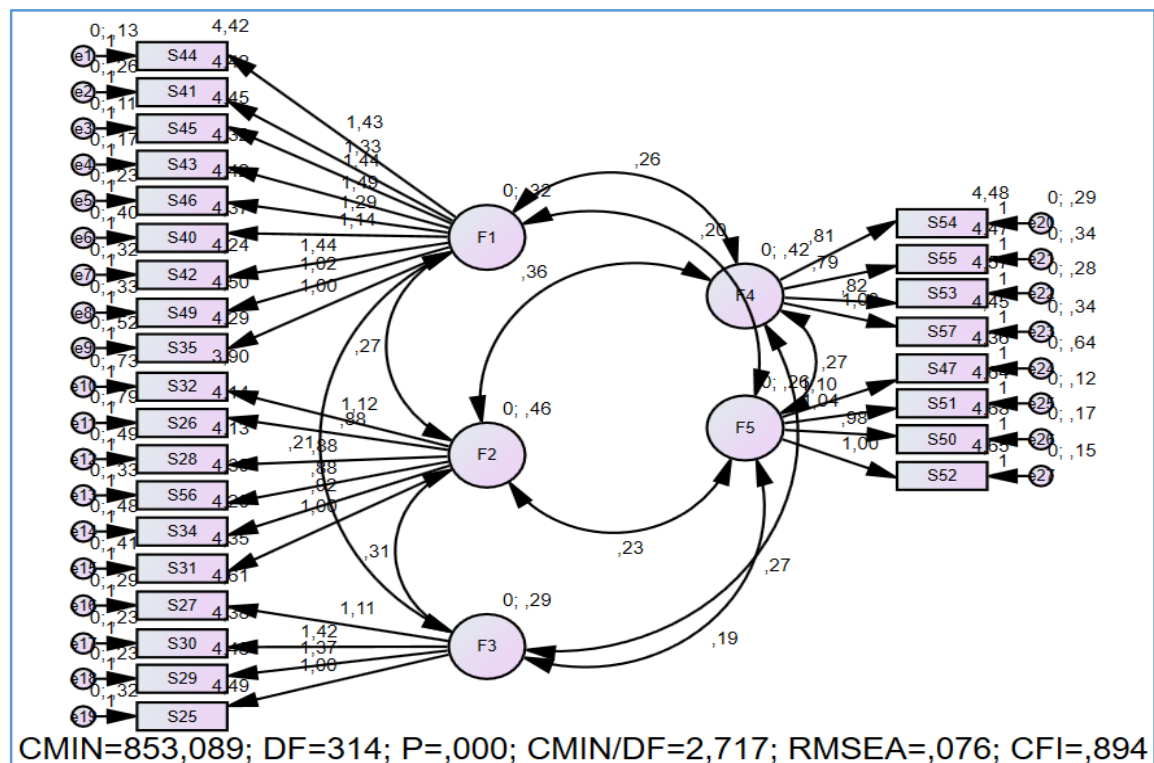

Figure 2. Confirmatory factor analysis non-standard path coefficients

Table 6. Confirmatory factor analysis results

\begin{tabular}{lccccccc}
\hline & & & B1 & B2 & Std. Error & Test Statistics & $\mathrm{p}$ \\
\hline S44 & $<---$ & F1 & 4.423 & 1.430 & 0.116 & 12.290 & $<0.001$ \\
S41 & $<--$ & F1 & 4.415 & 1.326 & 0.115 & 11.522 & $<0.001$ \\
S45 & $<---$ & F1 & 4.446 & 1.442 & 0.119 & 12.070 & $<0.001$ \\
S43 & $<---$ & F1 & 4.322 & 1.488 & 0.122 & 12.197 & $<0.001$ \\
S46 & $<---$ & F1 & 4.415 & 1.288 & 0.111 & 11.560 & $<0.001$ \\
S40 & $<---$ & F1 & 4.368 & 1.145 & 0.110 & 10.373 & $<0.001$ \\
S42 & $<---$ & F1 & 4.242 & 1.443 & 0.126 & 11.477 & $<0.001$ \\
S49 & $<---$ & F1 & 4.499 & 1.022 & 0.099 & 10.339 & $<0.001$ \\
S35 & $<---$ & F1 & 4.293 & 1 & & & \\
S32 & $<---$ & F2 & 3.895 & 1.121 & 0.104 & 10.768 & $<0.001$ \\
S26 & $<---$ & F2 & 4.145 & 0.876 & 0.097 & 8.998 & $<0.001$ \\
S28 & $<---$ & F2 & 4.130 & 0.879 & 0.083 & 10.534 & $<0.001$ \\
S56 & $<---$ & F2 & 4.394 & 0.885 & 0.075 & 11.745 & $<0.001$ \\
S34 & $<---$ & F2 & 4.198 & 0.921 & 0.085 & 10.851 & $<0.001$ \\
S31 & $<---$ & F2 & 4.349 & 1 & & & \\
S27 & $<---$ & F3 & 4.606 & 1.112 & 0.096 & 11.593 & $<0.001$ \\
S30 & $<---$ & F3 & 4.384 & 1.423 & 0.110 & 12.950 & $<0.001$ \\
S29 & $<---$ & F3 & 4.483 & 1.375 & 0.107 & 12.842 & $<0.001$ \\
S25 & $<---$ & F3 & 4.486 & 1 & & & \\
S54 & $<---$ & F4 & 4.485 & 0.811 & 0.071 & 11.379 & $<0.001$ \\
S55 & $<---$ & F4 & 4.468 & 0.794 & 0.074 & 10.792 & $<0.001$ \\
S53 & $<---$ & F4 & 4.570 & 0.816 & 0.071 & 11.527 & $<0.001$ \\
S57 & $<---$ & F4 & 4.452 & 1 & & & \\
S47 & $<---$ & F5 & 4.358 & 1.099 & 0.113 & 9.701 & $<0.001$ \\
S51 & $<---$ & F5 & 4.639 & 1.037 & 0.070 & 14.839 & $<0.001$ \\
S50 & $<---$ & F5 & 4.677 & 0.977 & 0.072 & 13.578 & $<0.001$ \\
S52 & $<---$ & F5 & 4.646 & 1 & & & \\
\hline & & B1: Stand & & \\
\hline
\end{tabular}

B1: Standard coefficient B2: Non-standard coefficient 
As a result of the confirmatory factor analysis, the path coefficients of the items under each factor were found to be statistically significant. Model fit coefficients are within the desired limits and the results are presented in Figure 2.

\section{Factor Analysis about the School Administrators Items}

The expectation scale had three items covering the administrators. In the scope of content validity, although it seems as if the items are not enough for measuring the role of the administrators, it is a fact that the administrators do not have any other role during this process as a stakeholder. Since the researcher had administered a pilot study before this scale and witnessed that the participants had no expectations concerning the administrators, the researcher found three items enough for this factor. The researcher didn't receive any feedback for increasing the number of items from the academicians when she took expert opinion. Thereby, only three items for measuring this factor is enough. There aren't any items eliminated in this subdivision. The items are about being recognized as a real teachers and getting informed about the rules.

Table 7. Expectation Scale Factor Analysis Results about the School Administrators Items

\begin{tabular}{cc}
\hline & Factor \\
\cline { 2 - 2 } & 1 \\
\hline S60 & 0.849 \\
S58 & 0.806 \\
S59 & 0.758 \\
Eigenvalue & 1.944 \\
VAO & 64.784 \\
KVAO & 64.784 \\
\hline
\end{tabular}

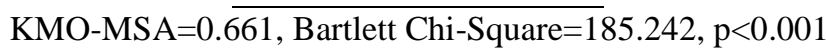

In the factor analysis made with a total of 3 items, the expectation scale has a sufficiently effective scale structure to measure the expectations in relation to the practicum school administrators (KMOMSA $=0.611$ ). This value reflects a medium scale structure. According to the Bartlett test, there are significant correlation levels between the items that reflect a certain structure, and the scale is the bit scale with two sub-dimensions ( $\mathrm{p}<0.001$ ). As a result of the factor analysis process, only 1 factor with an eigenvalue greater than 1 was obtained. Factor 1 explains $64.784 \%$ of the total variance. Factor 1 consists of S60, S58 and S59 items.

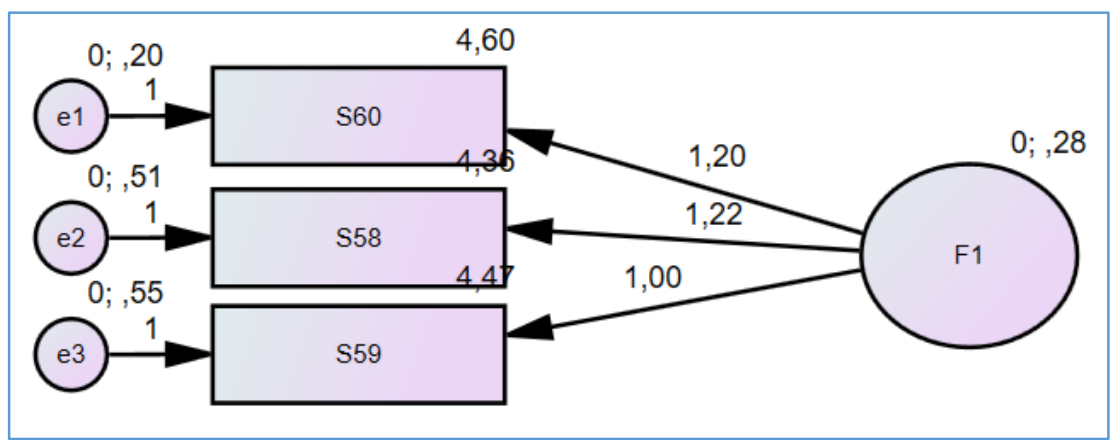

Figure 3. Confirmatory factor analysis non-standard path coefficients 
Table 8. Confirmatory factor analysis results

\begin{tabular}{cccccccc} 
& & \multicolumn{1}{c}{ B1 } & B2 & Std. Error & Test Statistics & $\mathrm{p}$ \\
\hline S60 & $<---$ & F1 & 4.605 & 1.198 & 0.165 & 7.264 & $<0.001$ \\
S58 & $<---$ & F1 & 4.361 & 1.225 & 0.157 & 7.782 & $<0.001$ \\
S59 & $<---$ & F1 & 4.467 & 1 & & & \\
\hline \multicolumn{7}{l}{ B1: Standard coefficient, B2: Non-Standard coefficient }
\end{tabular}

Path coefficients of all variables under the model were found to be significant.

\section{Factor Analysis about the Peer Pre-service Teachers Items}

The expectation scale had six items covering the peer pre-teachers. In the scope of content validity, although it seems as if the items are average for measuring the role of the peer teacher candidates, it is a fact that the peers have a limited role within the process. Since the researcher had administered a pilot study before this scale and witnessed that the participants had few expectations from their peers, the researcher found six items enough for this factor. The researcher didn't receive any feedback for increasing the number of items from the academicians when she got expert opinion. Thereby, six items for measuring this factor is enough. There aren't any items eliminated in this subdivision. The items are about receiving help and support from their friends within the process.

Table 9. Expectation Scale Factor Analysis Results about the Peer Pre-service Teachers Items

\begin{tabular}{ccc}
\hline & \multicolumn{1}{c}{ Factor } \\
\cline { 2 - 3 } S63 & 0.849 \\
S64 & 0.834 \\
S61 & 0.827 \\
S62 & 0.826 \\
S66 & 0.721 \\
S65 & 0.578 \\
Eigenvalue & 3.637 \\
VAO & 60613 \\
KVAO & 60.613 \\
\hline KMO-MSA $=0.835$, Bartlett Chi-Square $=872.490, \mathrm{p}<0.001$
\end{tabular}

In the factor analysis made with a total of 6 items, the expectation scale, has a sufficiently effective scale structure to measure the expectations in relation to peer pre-service teachers (KMO-MSA $=0.835$ ). This value reflects a very good scale structure. According to the Bartlett test, there are significant correlation levels between the items that reflect a certain structure, and the scale is the bit scale with two sub-dimensions ( $\mathrm{p}<0.001$ ). As a result of the factor analysis process, only 1 factor with an eigenvalue greater than 1 was obtained. Factor 1 explains $60.613 \%$ of the total variance. Factor 1 consists of S63, S64, S61, S62, S66 and S65 items. 


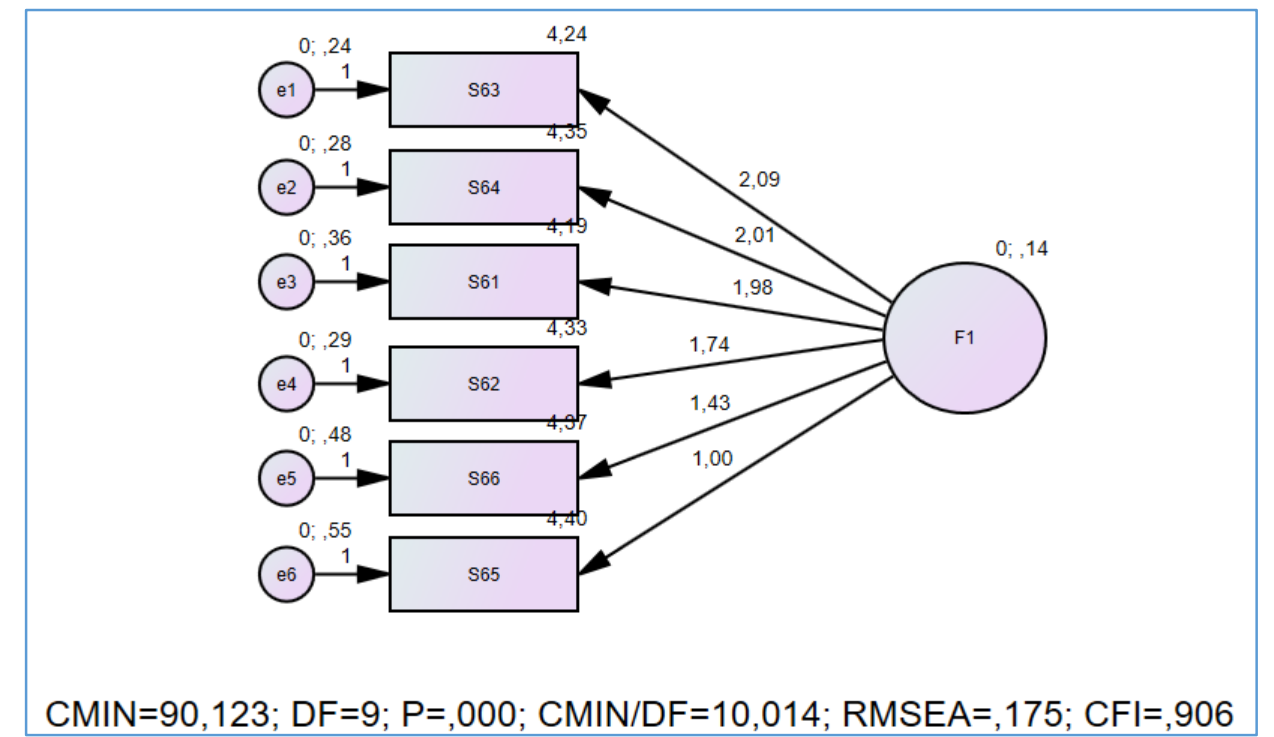

Figure 4. Confirmatory Factor analysis non-standard path coefficients

Table 10. Confirmatory Factor Analysis results

\begin{tabular}{|c|c|c|c|c|c|c|c|}
\hline & & & B1 & B2 & Std. Error & Test Statistics & $\mathrm{p}$ \\
\hline S63 & $<---$ & F1 & 0.852 & 2.093 & 0.267 & 7.850 & $<0.001$ \\
\hline S64 & $<--$ & F1 & 0.823 & 2.007 & 0.258 & 7.768 & $<0.001$ \\
\hline S61 & $<---$ & $\mathrm{F} 1$ & 0.782 & 1.979 & 0.259 & 7.634 & $<0.001$ \\
\hline S62 & $<---$ & F1 & 0.775 & 1.742 & 0.229 & 7.609 & $<0.001$ \\
\hline S66 & $<---$ & F1 & 0.619 & 1.433 & 0.207 & 6.926 & $<0.001$ \\
\hline S65 & $<---$ & F1 & 0.458 & 1 & & & \\
\hline
\end{tabular}

B1: Standart coefficient, B2: Non-Standard coefficient

Path coefficients of all variables under the model were found to be significant.

\section{Factor Analysis about the Students Items}

The expectation scale had only two items covering the expectations of teacher candidates from the students. In the scope of content validity, although it seems as if the items are scarce for measuring the role of the students, it is a fact that the students have a really limited role within the process. Since the researcher had administered a pilot study before this scale and witnessed that the participants had barely no expectations from their students, the researcher found two items enough for this factor. The researcher didn't receive any feedback for increasing the number of items from the academicians when she got expert opinion. Thereby, two items for measuring this factor is enough. There aren't any items eliminated in this subdivision. The items are about being seen as a real teacher and performing the tasks given.

Table 11. Expectation Scale Factor Analysis about the Students Items

\begin{tabular}{cc}
\hline & Factor \\
\cline { 2 - 2 } & 1 \\
\hline S68 & 0.893 \\
S67 & 0.893 \\
\hline
\end{tabular}




\begin{tabular}{cc}
\cline { 2 - 2 } Eigenvalue & 1.596 \\
VAO & 79.789 \\
KVAO & 79.789 \\
\cline { 2 - 2 } KVA & Bartlett Chi-Square $=125.169, \mathrm{p}<0.001$
\end{tabular}

In the factor analysis made with a total of 2 items, the expectation scale, has a sufficiently effective scale structure to measure the expectations in relation to the practicum school students (KMO-MSA = 0.500). This value reflects a weak scale structure. According to the Bartlett test, there are significant correlation levels between the items that reflect a certain structure, and the scale is the bit scale with two sub-dimensions ( $\mathrm{p}<0.001$ ). As a result of the factor analysis process, only 1 factor with an eigenvalue greater than 1 was obtained. Factor 1 explains $79.789 \%$ of the total variance. Factor 1 consists of S68 and S67 items.

\section{Factor Analysis about the Practicum School}

The expectation scale had six items covering the expectations of teacher candidates from the practicum school. This factor is mainly about the physical properties and facilities of the school because this is a non-living item. In the scope of content validity, although it seems as if the items are average for measuring the role of the school itself, it is a fact that having expectations from a component is not logical. Since the researcher had administered a pilot study before this scale and witnessed that the participants had barely no expectations in relation to a physical thing, the researcher found six items enough for this factor. The researcher didn't receive any feedback for increasing the number of items from the academicians when she got expert opinion. Thereby, six items for measuring this factor is enough. Only statement S75 is eliminated in this subdivision. The items are about physical and technical infrastructure mainly.

In the factor analysis made with a total of 7 items, the expectation scale has a sufficiently effective scale structure for measuring the expectations of the participants in relation to practicum school (KMOMSA $=0.804)$. This value reflects a very good scale structure. According to the Bartlett test, there are significant correlation levels between the items that reflect a certain structure, and the scale is the bit scale with two sub-dimensions ( $\mathrm{p}<0.001$ ). As a result of the factor analysis process, a total of 2 factors with an eigenvalue greater than 1 were obtained. When the factor loads of the items are examined, this item may represent both factors since there is a change of less than 0.10 between the loads of S75 in factor 1 and factor 2. For this reason, S75 must be removed from the scale.

Table 12. Expectation Scale Factor Analysis Results about the Practicum School Items

\begin{tabular}{ccc}
\hline & \multicolumn{2}{c}{ Rotated Factors } \\
\cline { 2 - 3 } S73 & 1 & 2 \\
S74 & 0.908 & \\
S72 & 0.819 & \\
S69 & 0.507 & \\
S70 & & 0.907 \\
S71 & & 0.718 \\
Eigenvalues & 2.991 & 1.058 \\
VAO & 43.404 & 24.076 \\
KVAO & 43.404 & 67.480 \\
\hline
\end{tabular}

KMO-MSA=0.759, Barlett Chi-Square $=604.139, \mathrm{p}<0.001$ 
In the factor analysis made by removing the S75 item, the expectation scale has a sufficiently effective scale structure to measure the expectations of the participants in relation to the practicum school (KMO-MSA = 0.759). This value reflects a good scale structure. According to the Barlett test, there are significant correlation levels between the items that reflect a certain structure and the scale is a bit scale with at least two sub-dimensions ( $\mathrm{p}<0.001$ ). As a result of the factor analysis process, a total of 2 factors with an eigenvalue greater than 1 were obtained. Factor 1 explains $43.404 \%$ of total variance and factor 2 explains $24.076 \%$, while these two factors together explain $67.480 \%$ of total variance. There are 4 items under factor 1 and 2 items under factor 2. F1 factor consists of S73, S74, S72 and S69 items, respectively, according to factor loads. The F2 factor consists of S70 and S71 items, respectively, according to factor loads.

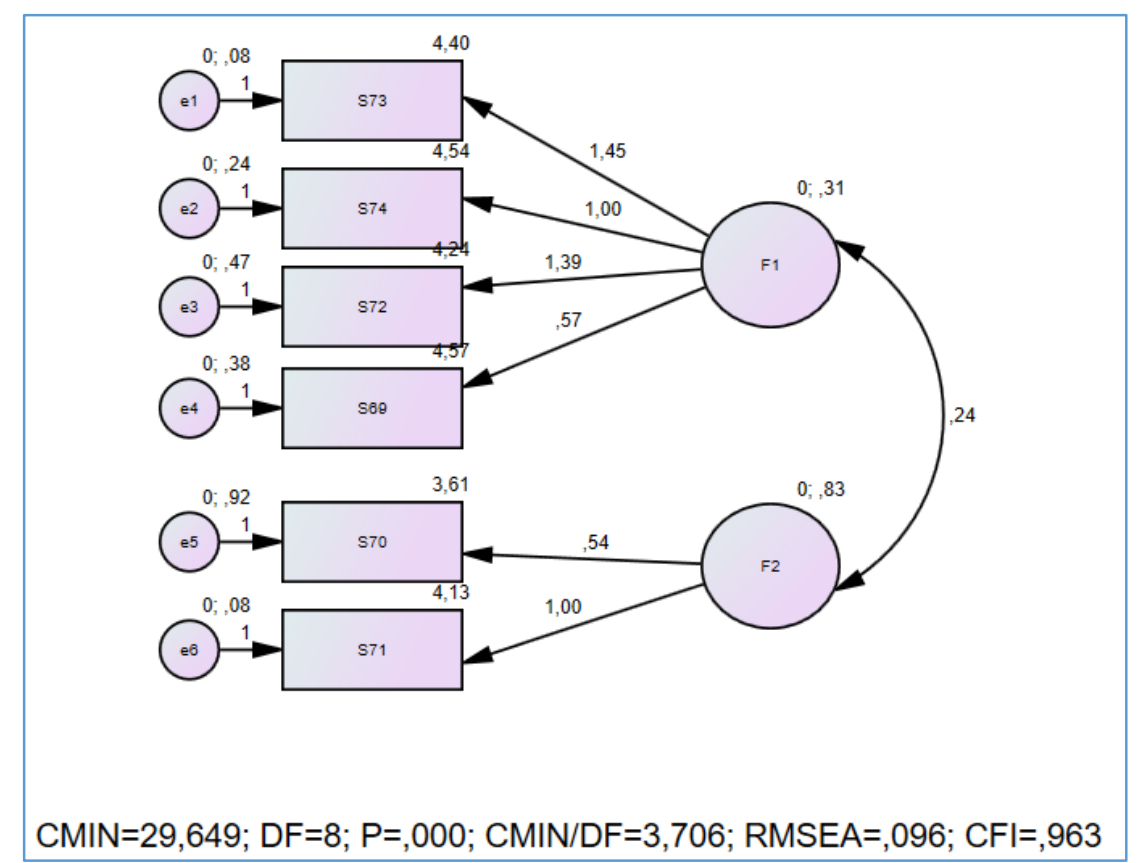

Figure 6. Confirmatory factor analysis non-standard path coefficients

Table 13. Confirmatory factor analysis results

\begin{tabular}{lllccccc}
\hline & & & & & Std. Error & Test Statistics & $\mathrm{p}$ \\
\hline S73 & $<---$ & F1 & 4.400 & 1.451 & 0.100 & 14.477 & $<0.001$ \\
S74 & $<---$ & F1 & 4.535 & 1.000 & & & $<0.001$ \\
S72 & $<---$ & F1 & 4.237 & 1.391 & 0.109 & 12.732 & $<0.001$ \\
S69 & $<---$ & F1 & 4.573 & 0.568 & 0.075 & 7.524 & $<0.001$ \\
S70 & $<---$ & F2 & 3.612 & 0.540 & 0.137 & 3.952 & $<0.001$ \\
S71 & $<---$ & F2 & 4.132 & 1.000 & & & \\
\hline
\end{tabular}

B1: Standard coefficient, B2: non-standard coefficient

Path coefficients of all variables under the model were found to be significant.

\section{Factor Analysis about the Teaching Practicum}

The expectation scale had seven items covering the expectations of teacher candidates from the teaching practicum itself. This factor is mainly about the procedural issues about the program. In the 
scope of content validity, seven items are enough for measuring the role of the program itself. Since the researcher had administered a pilot study before this scale and witnessed that the participants had barely no expectations in relation to a physical thing, the researcher found seven items enough for this factor. The researcher didn't receive any feedback for increasing the number of items from the academicians when she got expert opinion. Thereby, seven items for measuring this factor is enough. S77 and S78 are eliminated in this subdivision. The items are about social, economic, cultural traits, equality and meetings. The participants have no expectation regarding the item that states maximum student number should be four in groups because they have no idea about the process because they are thinking about the fun at the moment. The researcher thinks that they would want the group number to be lower when they see the timing and equality issues after they have practiced it in reality.

In the factor analysis made with a total of 8 items, the expectation scale has a sufficiently effective scale structure to measure the expectations of the participants in relation to teaching practicum (KMOMSA $=0.836$ ). This value reflects a very good scale structure. According to the Bartlett test, there are significant correlation levels between the items that reflect a certain structure, and the scale is the bit scale with two sub-dimensions ( $\mathrm{p}<0.001$ ). As a result of the factor analysis process, a total of 2 factors with an eigenvalue greater than 1 were obtained. When the factor loads of the items are examined, this item may represent both factors since there is a change of less than 0.10 between the loads of S78 item in factor 1 and factor 2. For this, S78 item should be removed from the scale.

Table 14. Expectation Scale Factor Analysis Results about the Teaching Practicum Items

\begin{tabular}{|c|c|}
\hline & Factor \\
\hline & 1 \\
\hline S81 & 0.791 \\
\hline S82 & 0.776 \\
\hline S83 & 0.727 \\
\hline S80 & 0.704 \\
\hline S79 & 0.699 \\
\hline S76 & 0.295 \\
\hline Eigenvalues & 2.830 \\
\hline VAO & 47.161 \\
\hline KVAO & 47.161 \\
\hline
\end{tabular}

KMO-MSA $=0.809$, Bartlett Chi-Square $=411.889, \mathrm{p}<0,001$

In the factor analysis made by removing S77 item, the expectation scale has a sufficiently effective scale structure to measure the expectations of the participants in relation to the teaching practicum $($ KMO-MSA $=0.809)$. This value reflects a very good scale structure. According to the Bartlett test, there are significant correlation levels between the items that reflect a certain structure and the scale is a bit scale with at least two sub-dimensions ( $\mathrm{p}<0.001$ ). As a result of the factor analysis process, only 1 factor with an eigenvalue greater than 1 was obtained. Factor 1 explains $47.161 \%$ of the total variance. Factor 1 consists of six items: S81, S82, S83, S80, S79 and S76. 


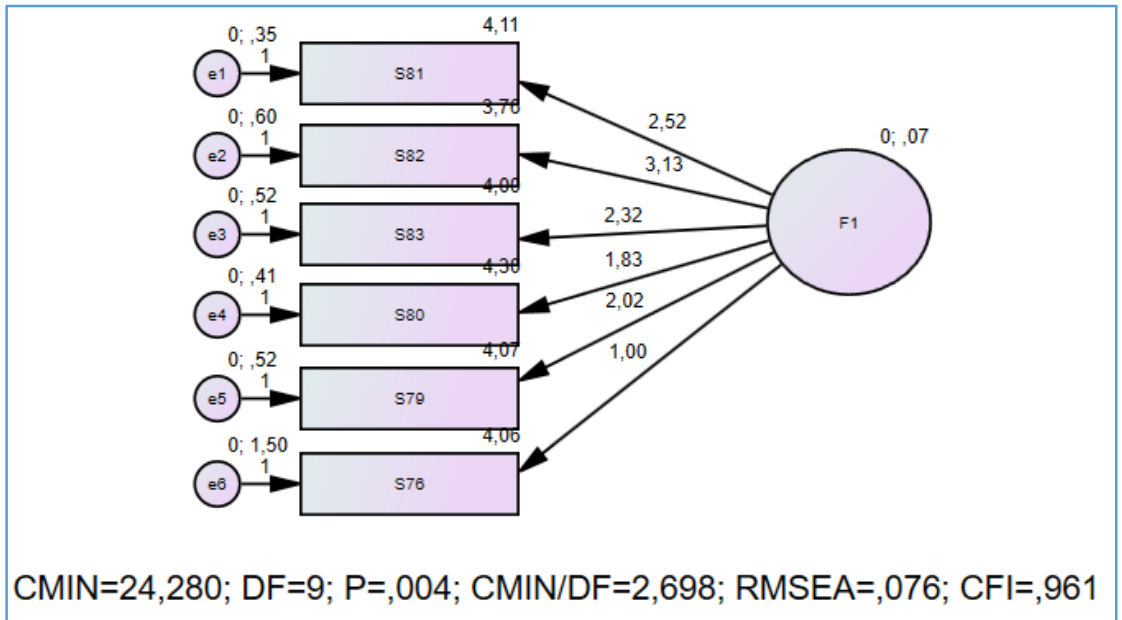

Figure 7. Confirmatory factor analysis non-standard path coefficients

Table 15. Confirmatory Factor Analysis Results

\begin{tabular}{|c|c|c|c|c|c|c|c|}
\hline & & & B1 & B2 & Std. Error & Test Statistics & $\mathrm{p}$ \\
\hline S81 & $<--$ & F1 & 4.105 & 2.519 & 0.802 & 3.141 & 0.002 \\
\hline S82 & $<---$ & $\mathrm{F} 1$ & 3.762 & 3.133 & 0.999 & 3.136 & 0.002 \\
\hline S83 & $<--$ & $\mathrm{F} 1$ & 4.003 & 2.321 & 0.748 & 3.103 & 0.002 \\
\hline S80 & $<---$ & $\mathrm{F} 1$ & 4.304 & 1.828 & 0.594 & 3.079 & 0.002 \\
\hline S79 & $<--$ & $\mathrm{F} 1$ & 4.075 & 2.024 & 0.658 & 3.076 & 0.002 \\
\hline S76 & $<---$ & $\mathrm{F} 1$ & 4.055 & 1 & & & \\
\hline
\end{tabular}

\section{Factor Analysis about the other Stakeholders}

The expectation scale had only two items covering the expectations of teacher candidates from the other stakeholders. In the scope of content validity, although it seems as if the items are scarce for measuring the role of other stakeholders, it is a fact that these items are mainly about the interaction among the factors mentioned in the scale before. Thereby, two items for measuring this interaction is enough. There aren't any items eliminated in this subdivision.

Table 16. Expectation Scale Factor Analysis Results about the other stakeholders Items

\begin{tabular}{cc}
\hline & Factor \\
\cline { 2 - 2 } S85 & 1 \\
S84 & 0.849 \\
Eigenvalue & 0.849 \\
VAO & 1.441 \\
KVAO & 72.070 \\
\hline A $=0.500$, Bartlett Chi-Square $=61.868$, & $\mathrm{p}<0.001$,
\end{tabular}

In the factor analysis made with a total of 2 items, the expectation scale has a sufficiently effective scale structure for measuring the expectations of the participants in relation to other stakeholders (KMO- 
MSA $=0.500$ ). This value reflects a weak scale structure. According to the Bartlett test, there are significant correlation levels between the items that reflect a certain structure, and the scale is the bit scale with two sub-dimensions ( $\mathrm{p}<0.001$ ). As a result of the factor analysis process, only 1 factor with an eigenvalue greater than 1 was obtained. Factor 1 explains $72.070 \%$ of the total variance. Factor 1 consists of S85 and S84 items.

\subsection{Reaction Scale Factor Analysis}

Exploratory and Confirmatory factor analysis was made for the reliability and validity of the reaction scale. It was supported with AMOS graphic program. Exploratory and Confirmatory factor analysis was made within each sub-division itself. It included 44 items at the beginning. After the analysis 5 items were eliminated from the scale and the scale was developed as a result.

Factor Analysis about the attitudes at the end of the practicum training

The reaction scale had 5 items covering the attitudes of participants at the end of practicum training. The items were mainly about rating the content of the program, the properties of mentor teacher, facilities and scheduling of the program.

As a result of the exploratory factor analysis no items had to be eliminated from the scale.

Table 17. Reaction Scale Factor Analysis Results about the attitudes at the end of teaching Practicum

\begin{tabular}{cc}
\hline & Factor \\
\cline { 2 - 2 } & 1 \\
\hline $\mathrm{A} 3$ & 0.836 \\
$\mathrm{~A} 1$ & 0.805 \\
$\mathrm{~A} 4$ & 0.805 \\
$\mathrm{~A} 2$ & 0.766 \\
$\mathrm{~A} 5$ & 0.758 \\
Eigenvalue & 3.156 \\
VAO & 63.124 \\
KVAO & 63.124 \\
\hline
\end{tabular}

KMO-MS $\overline{\mathrm{A}=0.851 \text {, Bartlett Chi-Square }=57.244}, \mathrm{p}<0.001$,

In the factor analysis made with a total of 5 items, the reaction scale has a sufficiently effective scale structure to measure the attitudes of the participants as a teacher candidate at the end of the practicum $($ KMO-MSA $=0.500)$. This value reflects a weak scale structure. According to the Bartlett test, there are significant correlation levels between the items that reflect a certain structure and the scale has two sub-dimensions. Only one factor with eigenvalue greater than 1 was obtained under factor analysis. Factor 1 can explain $73.124 \%$ of the total variance. Factor 1 consists of items A3, A1, A4, A2 and A5. 


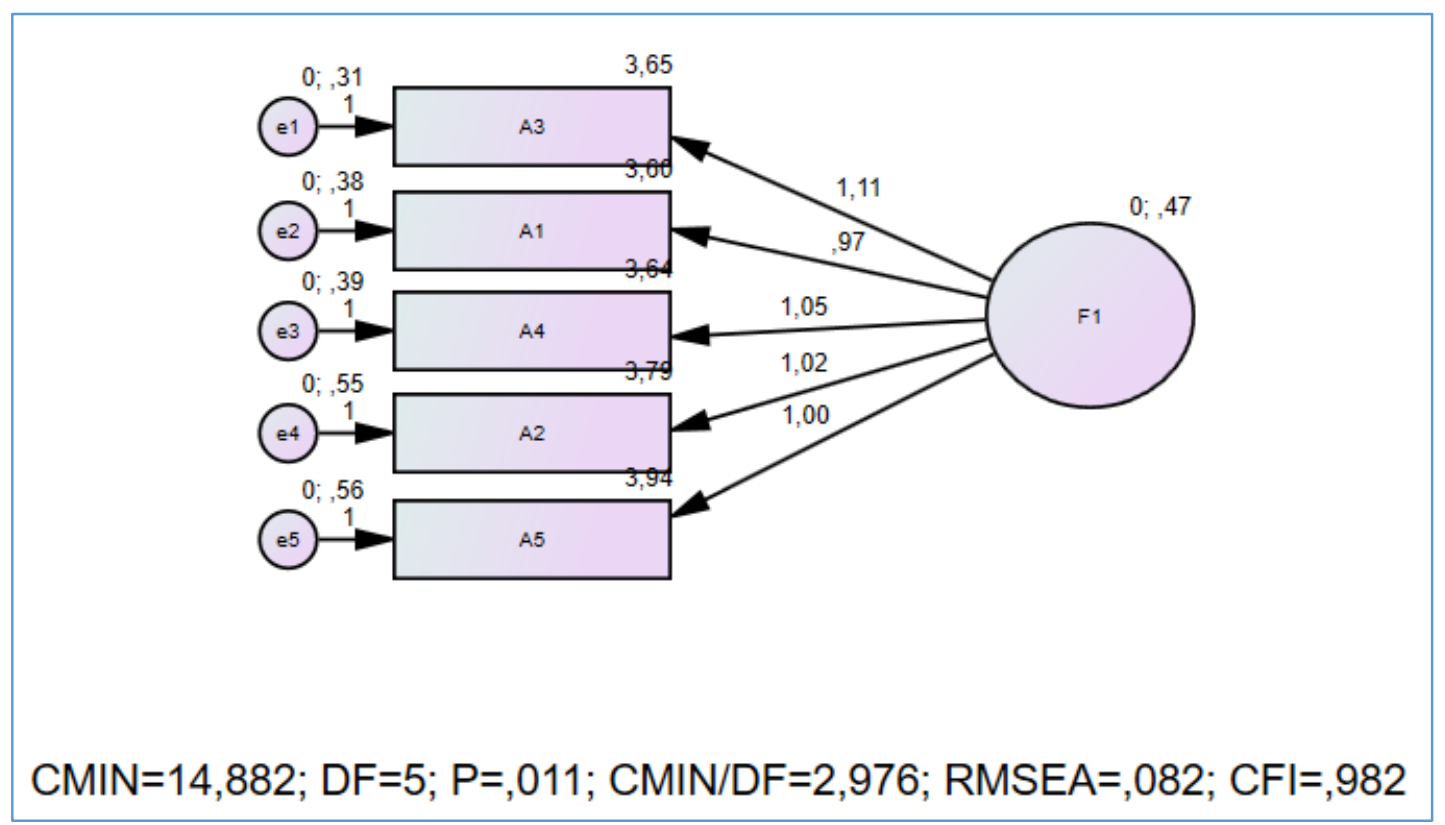

Figure 9. Confirmatory factor analysis non-standard path coefficients

Table 18. Confirmatory factor analysis results

\begin{tabular}{lllrrrrr}
\hline & & & B1 & B2 & SH & Test Statistics & p \\
\hline A3 & $<---$ & F1 & 3.650 & 1.107 & 0.097 & 11.415 & $<0.001$ \\
A1 & $<---$ & F1 & 3.601 & 0.975 & 0.091 & 10.668 & $<0.001$ \\
A4 & $<---$ & F1 & 3.644 & 1.054 & 0.097 & 10.908 & $<0.001$ \\
A2 & $<---$ & F1 & 3.794 & 1.024 & 0.102 & 10.061 & $<0.001$ \\
A5 & $<---$ & F1 & 3.944 & 1.000 & & & $<0.001$ \\
\hline
\end{tabular}

B1: Standard coefficient, B2: Non-standard coefficient

Reaction Scale Factor Analysis about the attitudes in relation to teaching practicum

The reaction scale had 12 items covering the attitudes of participants in relation to the teaching practicum. The items were mainly about the content of the program, the quality of the mentor teacher and how it could have been better by improving some facilities.

As a result of the exploratory factor analysis attitude item A16 was eliminated from the scale only. This items asked the participants about the relationship between themselves and the mentor teacher. Since this item included some emotional issues and is difficult to assess, it is evident that the replies given to this item made it to be eliminated. The participants do not believe that they have a good relationship with the mentor teacher.

In factor analysis with a total of 12 items, the attitude scale has a sufficiently effective scale structure to measure the attitudes of the participants regarding the practicum program (KMO-MSA $=0.823)$. This value reflects a very good scale structure. According to the Bartlett test, there are significant correlation levels between the items that reflect a certain structure, and the scale is the bit scale with two subdimensions $(p<0.001)$. As a result of the factor analysis process, a total of 3 factors with eigenvalues greater than 1 were obtained. When the factor loads of the items are analyzed, this item may represent both factors, since there is a change of less than 0.10 between the loads of item A16 in factor 1 and factor 2. For this, item A16 must be removed from the scale. 
Table 19. Reaction Scale Factor Analysis Results about the attitudes in relation to teaching practicum

\begin{tabular}{cccc}
\hline & \multicolumn{3}{c}{ Rotated Factors } \\
\cline { 2 - 4 } A13 & 0.752 & 3 \\
A17 & 0.738 & \\
A14 & 0.712 & \\
A7 & 0.692 & & \\
A6 & 0.682 & & \\
A9 & & 0.866 & \\
A8 & & 0.843 & \\
A15 & & 0.708 & 0.896 \\
A11 & \multicolumn{4}{c}{0.823} \\
A10 & & & 0.721 \\
A12 & & & 1.105 \\
Eigenvalues & 4.656 & 1.620 & 19.834 \\
VAO & 25.406 & 21.857 & 67.098 \\
KVAO & 25.406 & 47.263 & \\
\hline KMO-MSA=0.818, Bartlett Chi-Square $=1340.573, \mathrm{p}<0.001$,
\end{tabular}

In factor analysis made by subtracting the A16 item, the reaction scale has a sufficiently effective scale structure to measure the attitudes of the participants regarding the teaching practicum program $($ KMO-MSA $=0.818)$. This value reflects a very good scale structure. According to the Bartlett test, there are significant correlation levels between the items that reflect a certain structure and the scale is a bit scale with at least two sub-dimensions $(\mathrm{p}<0.001)$. As a result of the factor analysis process, a total of 3 factors with eigenvalues greater than 1 were obtained. Factor 1 explains $25.406 \%$ of total variance, factor 2 explains $21.857 \%$ of total variance and factor 3 explains $19.834 \%$, while these three factors together explain $67.098 \%$ of total variance. There are 5 items under factor 1, 3 items under factor 2 and 3 items under factor 3. F1 factor consists of A3, A17, A14, A7 and A6 items according to factor loads, respectively. The $\mathrm{F} 2$ factor consists of items A9, A8 and A15, respectively, according to factor loads. Factor 3 consists of items A10, A11 and A12. 


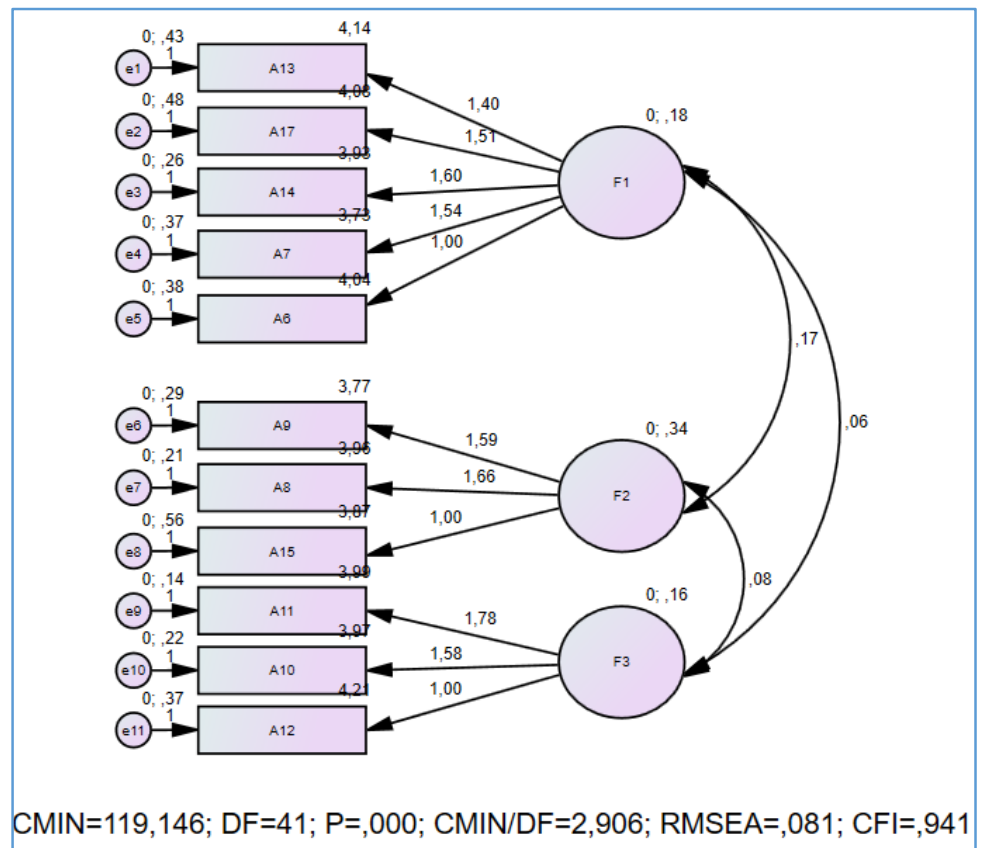

Figure 10. Confirmatory factor analysis non-standard path coefficients

Table 20. Confirmatory factor analysis results

\begin{tabular}{cccccccc}
\hline & & & B1 & B2 & SH & Test Statistics & p \\
\hline A13 & $<---$ & F1 & 4.142 & 1.399 & 0.167 & 8.387 & $<0.001$ \\
A17 & $<---$ & F1 & 4.082 & 1.509 & 0.179 & 8.419 & $<0.001$ \\
A14 & $<---$ & F1 & 3.934 & 1.601 & 0.173 & 9.244 & $<0.001$ \\
A7 & $<---$ & F1 & 3.73 & 1.543 & 0.175 & 8.793 & $<0.001$ \\
A6 & $<---$ & F1 & 4.043 & 1 & & & \\
A9 & $<---$ & F2 & 3.769 & 1.59 & 0.144 & 11.009 & $<0.001$ \\
A8 & $<---$ & F2 & 3.958 & 1.665 & 0.15 & 11.106 & $<0.001$ \\
A15 & $<---$ & F2 & 3.871 & 1 & & & \\
A11 & $<---$ & F3 & 3.987 & 1.776 & 0.2 & 8.893 & $<0.001$ \\
A10 & $<---$ & F3 & 3.972 & 1.577 & 0.174 & 9.086 & $<0.001$ \\
A12 & $<---$ & F3 & 4.208 & 1 & & & \\
\hline
\end{tabular}

B1: Standard coefficient, B2: Non-standard coefficient

Reaction Scale Factor Analysis about the pre-service teachers' reactions about teaching practicum

The reaction scale had 27 items covering the reactions of pre-service teachers in relation to the teaching practicum. The items were mainly positive items about the progress made by the teacher candidates and it what areas they improved their ways of teaching such as improving self-confidence, learning how to grade students, establishing a good relationship etc.

As a result of the factor analysis attitudes A31, A32, A42 and A44 were eliminated from the scale. These items were mainly really self-confident statements about the teacher candidates in which they stated they learned to utilize many sources, solved all their problems, learned to teach according to all the proficiency levels and learned to use their voicing effectively. It is a fact that the candidates know that learning to be an effective teacher needs times and this can't be handled with a few-months lasting practice. So they refrain from stating big sentences. 
In the factor analysis made with a total of 27 items, the attitude scale has a sufficiently effective scale structure to measure the attitudes of the participants regarding teacher internship attitudes (KMO-MSA $=0.918)$. This value reflects an excellent scale structure. According to the Bartlett test, there are significant correlation levels between the items that reflect a certain structure, and the scale is the bit scale with two sub-dimensions ( $\mathrm{p}<0.001$ ). As a result of factor analysis, a total of 6 factors with eigenvalues greater than 1 were obtained. When the factor loads of the items are examined, these items may represent both factors since there is a change of less than 0.10 between factor 1 and factor 3 in factor A, item A31 in factor 1 and factor 2. For this, items A31 and A32 must be removed from the scale.

Table 21. Reaction Scale Factor Analysis Results about pre-service teachers reactions in relation to teaching practicum

\section{Rotated Factors}

\begin{tabular}{|c|c|c|c|c|}
\hline & 1 & 2 & 3 & 4 \\
\hline A19 & 0.792 & & & \\
\hline A18 & 0.757 & & & \\
\hline $\mathrm{A} 22$ & 0.739 & & & \\
\hline A37 & 0.719 & & & \\
\hline A27 & 0.694 & & & \\
\hline A28 & 0.691 & & & \\
\hline A 25 & 0.669 & & & \\
\hline A23 & 0.667 & & & \\
\hline A36 & 0.659 & & & \\
\hline $\mathrm{A} 30$ & 0.614 & & & \\
\hline $\mathrm{A} 43$ & 0.600 & & & \\
\hline A39 & & 0.824 & & \\
\hline A38 & & 0.786 & & \\
\hline A40 & & 0.770 & & \\
\hline A41 & & 0.689 & & \\
\hline A24 & & 0.574 & & \\
\hline A29 & & 0.561 & & \\
\hline A34 & & & 0.852 & \\
\hline A33 & & & 0.807 & \\
\hline A35 & & & 0.696 & \\
\hline A 20 & & & & 0,911 \\
\hline A21 & & & & 0,872 \\
\hline A26 & & & & 0,856 \\
\hline Eigenvalues & 9.322 & 2.083 & 1.512 & 1.408 \\
\hline VAO & 26.252 & 17.112 & 9.992 & 8.595 \\
\hline KVAO & 26.252 & 43.363 & 53.356 & 61.951 \\
\hline
\end{tabular}

In factor analysis made by removing A42 and A44 items, the attitude scale has a sufficiently effective scale structure to measure the pre-service teachers reactions about the teaching practicum (KMO-MSA $=0.908)$. This value reflects an excellent scale structure. According to the Bartlett test, there are significant correlation levels between the items that reflect a certain structure and the scale is a bit scale with at least two sub-dimensions ( $\mathrm{p}<0.001$ ). As a result of the factor analysis process, a total of 5 factors 
with eigenvalues greater than 1 were obtained. Since there will be no single substance under the 5 th factor, treatment was performed on 4 factors. Factor 1 explains $26.252 \%$ of total variance, factor 2 explains $17.112 \%$ of total variance, factor 3 explains $9.992 \%$ of total variance, factor 4 explains $8.595 \%$ of total variance, while these four factors together explain $61.951 \%$ of total variance. There are 11 items under factor 1, 6 items under factor 2, 3 items under factor 3 and 3 items under factor 4 . F1 factor consists of items A19, A18, A22, A37, A27, A28, A25, A23, A36, A30 and A43, respectively, according to factor loads. F2 factor consists of items A39, A38, A40, A41, A24 and A29, respectively, according to factor loads. Factor 3 consists of items A34, A33 and A35. Factor 4 consists of items A20, A21 and A26.

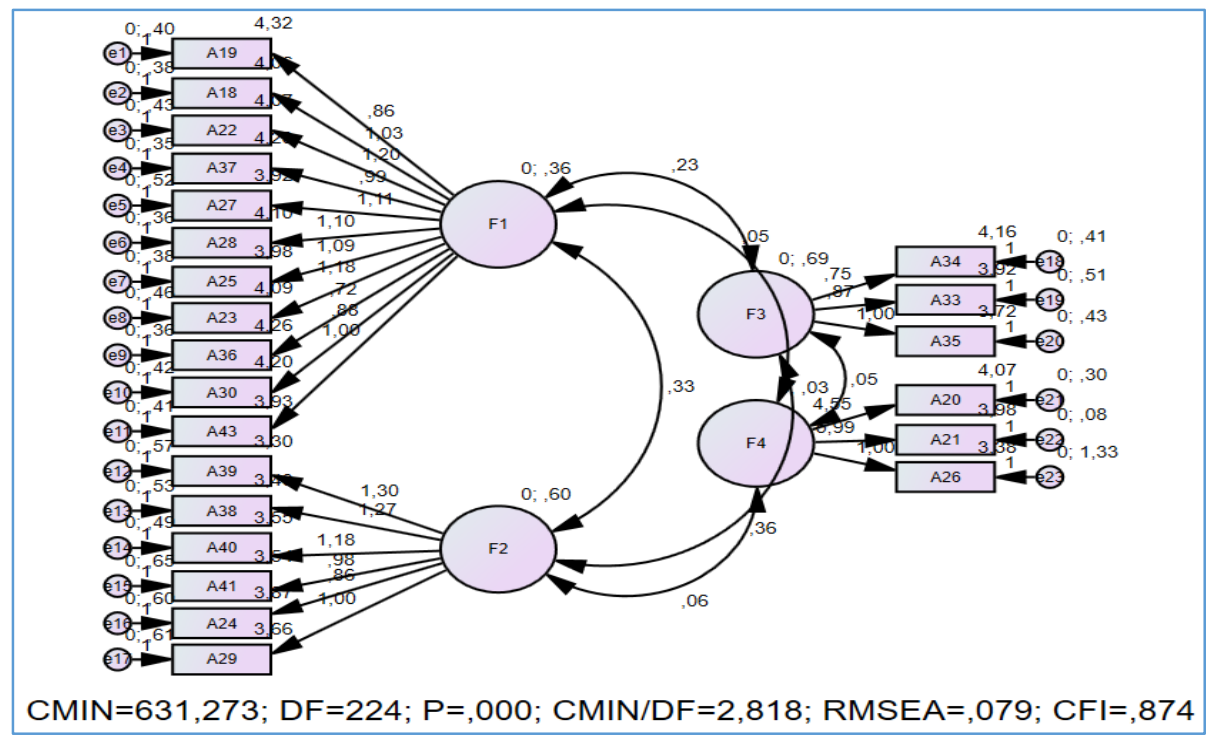

Figure 11. Confirmatory factor analysis non-standard path coefficients

Table 22. Confirmatory Factor Analysis Results

\begin{tabular}{llllllll}
\hline & & & & & & Test & p \\
& & & B1 & B2 & SH & Statistics & \\
A19 & $<---$ & F1 & 4.323 & 0.863 & 0.087 & 9.871 & $<0.001$ \\
A18 & $<---$ & F1 & 4.06 & 1.033 & 0.094 & 10.947 & $<0.001$ \\
A22 & $<---$ & F1 & 4.067 & 1.203 & 0.105 & 11.414 & $<0.001$ \\
A37 & $<---$ & F1 & 4.229 & 0.993 & 0.091 & 10.918 & $<0.001$ \\
A27 & $<---$ & F1 & 3.919 & 1.113 & 0.106 & 10.532 & $<0.001$ \\
A28 & $<---$ & F1 & 4.101 & 1.098 & 0.096 & 11.383 & $<0.001$ \\
A25 & $<---$ & F1 & 3.979 & 1.089 & 0.097 & 11.214 & $<0.001$ \\
A23 & $<---$ & F1 & 4.092 & 1.183 & 0.106 & 11.148 & $<0.001$ \\
A36 & $<---$ & F1 & 4.259 & 0.723 & 0.079 & 9.165 & $<0.001$ \\
A30 & $<---$ & F1 & 4.197 & 0.879 & 0.09 & 9.792 & $<0.001$ \\
A43 & $<---$ & F1 & 3.931 & 1 & & & $<0.001$ \\
A39 & $<---$ & F2 & 3.299 & 1.301 & 0.105 & 12.379 & $<0.001$ \\
A38 & $<---$ & F2 & 3.402 & 1.267 & 0.102 & 12.437 & $<0.001$ \\
A40 & $<---$ & F2 & 3.551 & 1.185 & 0.103 & 11.527 & $<0.001$ \\
A41 & $<---$ & F2 & 3.54 & 0.978 & 0.091 & 10.689 & $<0.001$ \\
A24 & $<---$ & F2 & 3.868 & 0.859 & 0.084 & 10.222 & \\
A29 & $<---$ & F2 & 3.658 & 1 & & &
\end{tabular}




\begin{tabular}{cccccccc} 
A34 & $<---$ & F3 & 4.159 & 0.747 & 0.075 & 9.978 & $<0.001$ \\
A33 & $<--$ & F3 & 3.922 & 0.868 & 0.086 & 10.144 & $<0.001$ \\
A35 & $<---$ & F3 & 3.72 & 1 & & & \\
A20 & $<---$ & F4 & 4.074 & 4.551 & 1.856 & 2.452 & 0.014 \\
A21 & $<---$ & F4 & 3.98 & 5.989 & 2.461 & 2.433 & 0.015 \\
A26 & $<---$ & F4 & 3.383 & 1 & & & \\
\hline
\end{tabular}

B1: Standard coefficient, B2: Non-standard coefficient

All path coefficients of the model were found statistically significant. Analysis results and compliance values were obtained within the desired limits and the results are presented in Figure 11.

\section{Discussion}

Developing a new measurement tool is always a complex process. Many authors (Clark and Watson 1995; DeVellis, 2017) confirm that the scale development process involves complex systematic procedures that demand theoretical and methodological rigor. Among the scaling methods, Likert Type Scaling Technique is preferred mostly. As the first step, commonly known as "item generation," the researcher provides theoretical support for the initial item pool (Hutz et al., 2015). As the second step, usually known as the "theoretical analysis," the researcher assesses the content validity of the new scale, by ensuring that the initial item pool reflects the desired construct (Arias et al., 2014). In order to ensure the content validity, the researcher gets the opinions of expert judges who are experts in the development scales or experts in the target construct to ensure that the hypothesis of the research represents the construct of interest appropriately (Nunnally, 1967). As the final step, the researcher assesses whether the new scale has construct validity and reliability. Construct validity can be assessed with the use of exploratory factor analysis (EFA), confirmatory factor analysis (CFA), or with convergent, discriminant, predictive/nomological, criterion, internal, and external validity while reliability is usually measured by use of internal consistency, test-retest reliability, split-half, item-total correlation/inter-item reliability, and inter-observer reliability (DeVellis, 2017). For maintaining construct validity and reliability, the data should be collected in a large and appropriately representative sample of the target population. And this study tried to contribute to the development of valid and reliable measurement tool by researchers in teaching practicum in English Language Teaching. Structural Equation Modelling was used for this purpose. EFA and CFA statistics are the most important analyses of this scientific method and were used specifically for this study. Results of the study showed that the instrument is valid and reliable and could be used to measure pre-service English teachers' expectations and reactions regarding their teaching practicum. The expectation scale included eight-dimensions. The expectation scale consisted of 85 items in 5-point Likert type. The scale had 8 sub-branches; a) university supervisors, b) mentor teachers, c) school administrators, d) peer pre-service teachers, e) students, f) practicum school, g) teaching practicum and $h$ ) other stakeholders. The pre-service teachers rated the items of the instrument on a scale (1 strongly disagree) to 5 (strongly agree). Cronbach's alpha coefficients were calculated as . between .89 the lowest and .96 the highest for the instrument. 12 items were decided to be removed from the scale. The reaction scale consisted of 44 items in Likert type. The scale had 3 sub-dimensions;

a) attitudes at the end of the practicum training as a teacher candidate, b) attitudes in relation to the teaching practicum and c) pre-service teachers reactions about teaching practicum. CFI values for the sub- scales were found as $.982, .941$, and .874 , respectively. 5 items were decided to be removed from the scale. 


\section{Conclusion}

This study focused on examining the validity and reliability of the Teaching Practicum Expectation and Reaction Scales for pre-service English teachers developed by the researchers. Studies which aim to determine attitudes generally, use measurement tools developed abroad and adapt them to Turkish. When a scale is developed in another culture and has been adapted to Turkish, it is a generally a disadvantage that it is not suitable for Turkish culture. Henceforth, the researchers specifically wanted to develop their own scales. It was found that the instruments are valid, reliable and appropriate to use in Turkish culture. In this study, data were collected from pre-service English teachers. This instrument can also be used for the pre- service teachers majoring in different areas such as Turkish, social studies, science or mathematics education programs as well. As understood from the previous studies, since the cooperating teacher and the practicum have very strong influences in the development of teacher identity, practicum needs much more care (Koç, 2012). It is of utmost importance that preservice teachers experience a practicum period in which they can develop effective teaching skills. However, they assume that they are not given the chance to reflect on their knowledge and expectations during this process. So, the development of an expectation and reaction scale related to teaching practicum sheds light onto this problem. The ideas of the participants may be contributory to redesign the teacher preparation programs at least in our country. The results will be presented to the Ministry of Education in Teaching Practicum Manual and Faculty-School Cooperation Report formats at the end of the study.

\section{Ethics Committee Approval}

The author confirms that ethical approval was obtained from Hacettepe University (Approval Date: 23/09/2019).

\section{References}

Arias, M. R. M., Lloreda, M. J. H., \& Lloreda, M. V. H. (2014). Psicometría. S.A.: Alianza Editorial

Boz, N., \& Boz, Y. (2006). Do prospective teachers get enough experience in school placements? Journal of Education for Teaching, 32(4), 353-368.

Clark, L. A., \& Watson, D. (1995). Constructing validity: basic issues in objective scale development. Psychological Assessment, 7(3), 309-319.

Cook, L. (2007). "When in Rome: Influences on special education student teachers' teaching." International Journal of Special Education, 22(3), 119-130.

DeVellis, R. F. (2017). Scale development: Theory and applications. Thousand Oaks, Calif: Sage Publications.

Çevik, C. \& Alat, K. (2012). “Uygulama öğretmenlerinin öğretmenlik uygulaması dersine yönelik tutum ölçeği geliştirilmesi.” Uludağ Üniversitesi Eğitim Fakültesi Dergisi 25(2), 359-380.

Gan, Z. (2014). Learning from interpersonal interactions during the practicum: a case study of nonnative ESL student teachers. Journal of Education for Teaching: International Research and Pedagogy, 40(2), 128-139.

Hascher, H. , Cocard, Y. \& Moser, P. (2004). Forget about theory - practice is all? Student teachers' learning in practicum. Teachers and Teaching: Theory and Practice,10(6), 623-637. 
Hudson, P. (2009). "Mentoring preservice teachers in primary mathematics." The International Journal of Learning, 16(4), 119-132.

Hutz, CS, Bandeira, DR, \& Trentini, CM. (2015). Psicometria. Artmed.

Kiraz, E. (2003). "Uygulama öğretmeni yeterlik ölçeği: Ölçü aracı geliştirme örneği.” Türk Eğitim Bilimleri Dergisi, 4(1), 387-400.

Kirkpatrick, D. L. (2000). Evaluating training programs: The four levels-The ASTD handbook of training design and delivery. VA: The American society of training and development. McGraw-Hill.

Koc, I. (2012) Pre-service science teachers reflect on their practicum experiences: Educational Studies, $V(38), 31-38$.

Kolb, D. (1984). Experiential learning: Experience as the source of learning and development. Englewood Cliffs, NJ: Prentice Hall.

Nunnally, J. C. (1967). Psychometric theory. McGraw Hill.

Ronfeldt, M. \& Reinninger, M. (2012). "More or better student teaching?" Teaching and teacher education, 28(8), 1091-1106.

Seferoğlu, G. (2006). Teacher candidates' reflections on some components of a pre-service English language teacher education program in Turkey. Journal of Education for Teaching, 32(4), 369-378.

Smagorinsky, P., Sanford, A. D., and Konopak, B. (2006). "Functional literacy in a Constructivist Key: A nontraditional Student Teacher's Apprenticeship in a Rural Elementary School." Teacher Education Quarterly, 33(4), 93-109.

Zeichner, K. (2002). "Beyond traditional structures of student teaching.” Teacher Education Quarterly, 29(2), 59-64.

\section{Appendix A: Eigen Value Line Graphs}

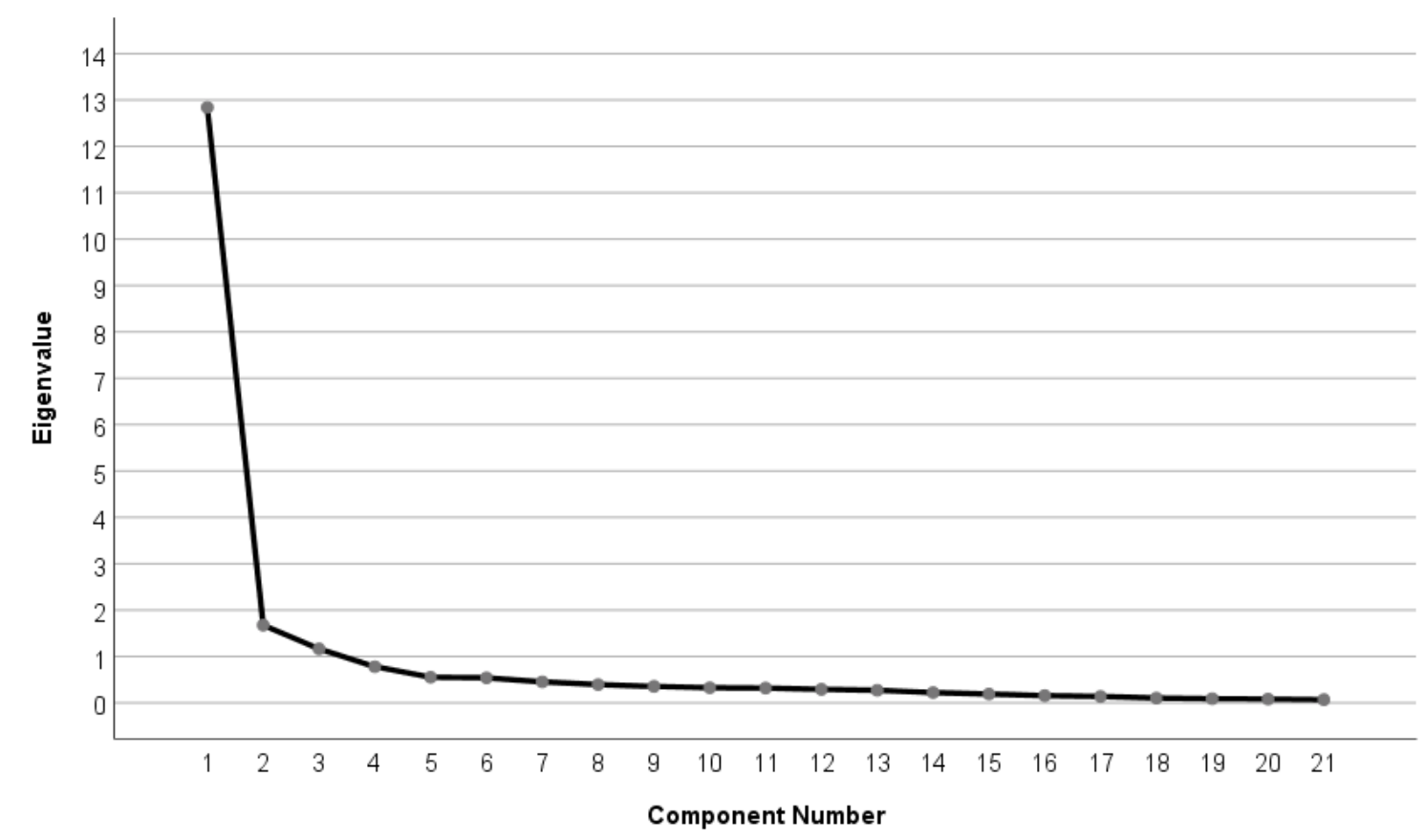


Graph 1. Factor analysis line graph of the items created for the university supervisors belonging to the expectation scale (Eigen Values 12.839, 1.676, 1.164)

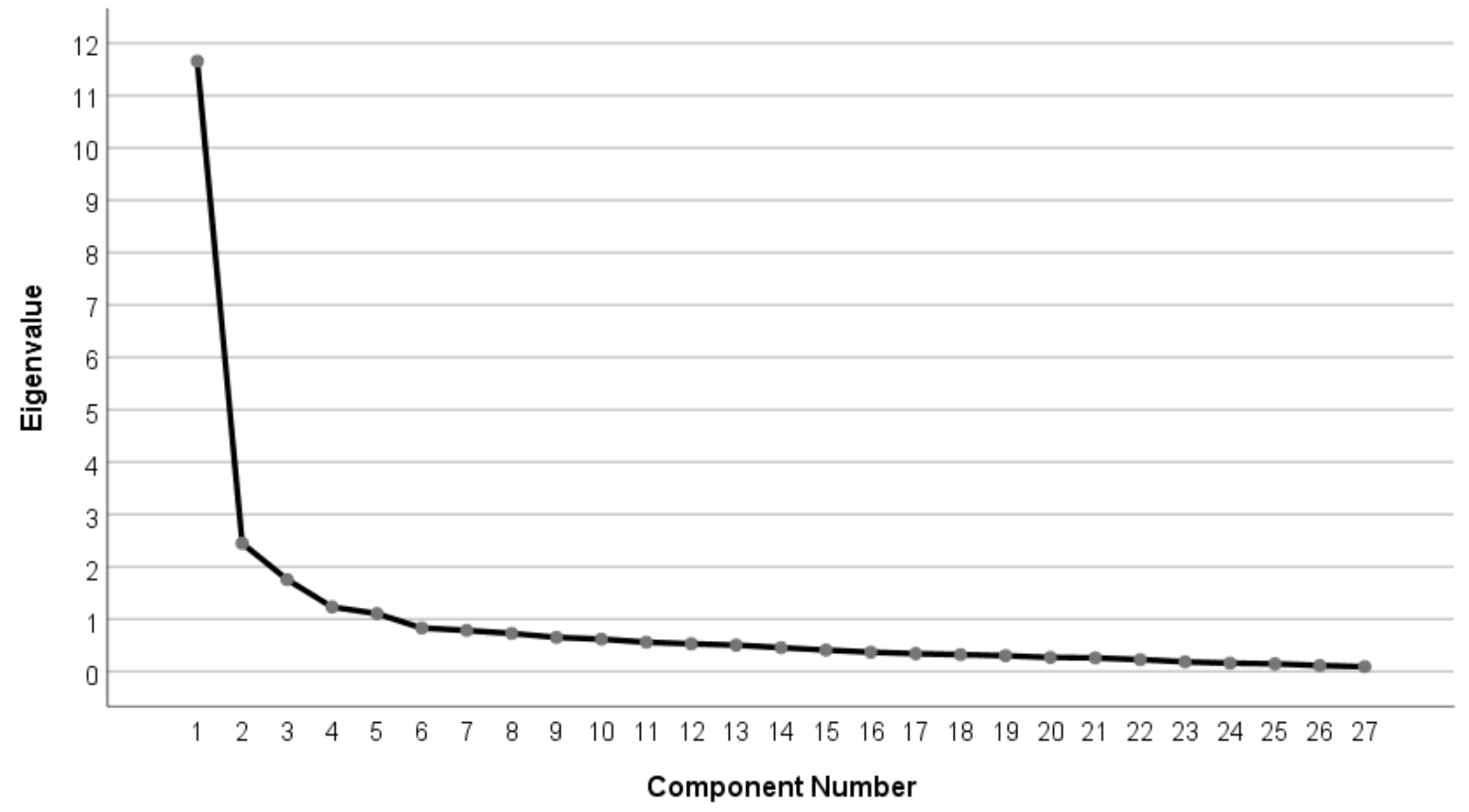

Graph 2. Factor analysis line graph of the items created for the mentor teachers belonging to the expectation scale (Eigen Values 11.656, 2.447, 1.754, 1.231, 1.104)

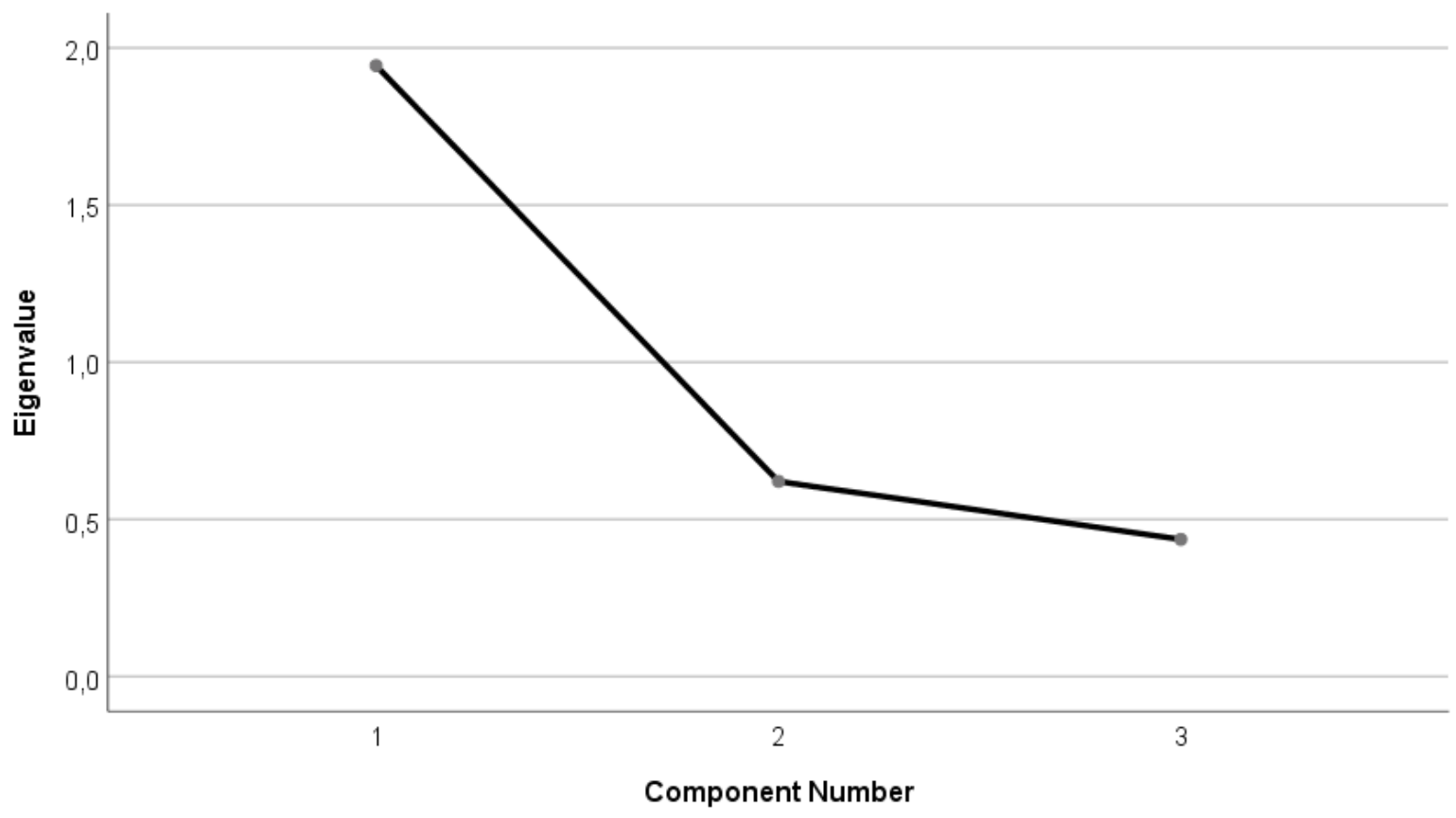

Graph 3. Factor analysis line graph of the items created for the school administrators belonging to the expectation scale (Eigen Value 1.944) 


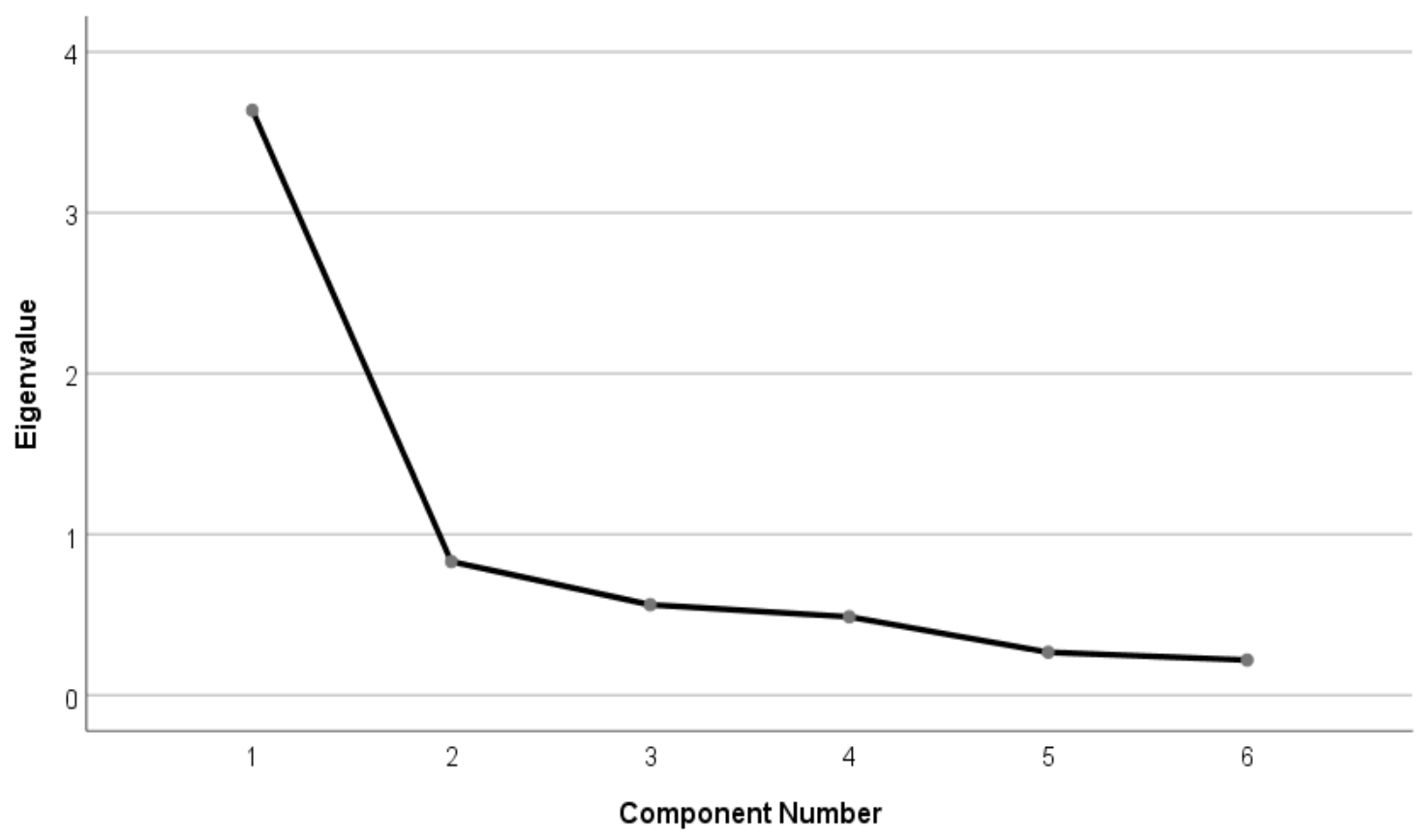

Graph 4. Factor analysis line graph of the items created for the peer pre-service teachers belonging to the expectation scale (Eigen Value 3.637)

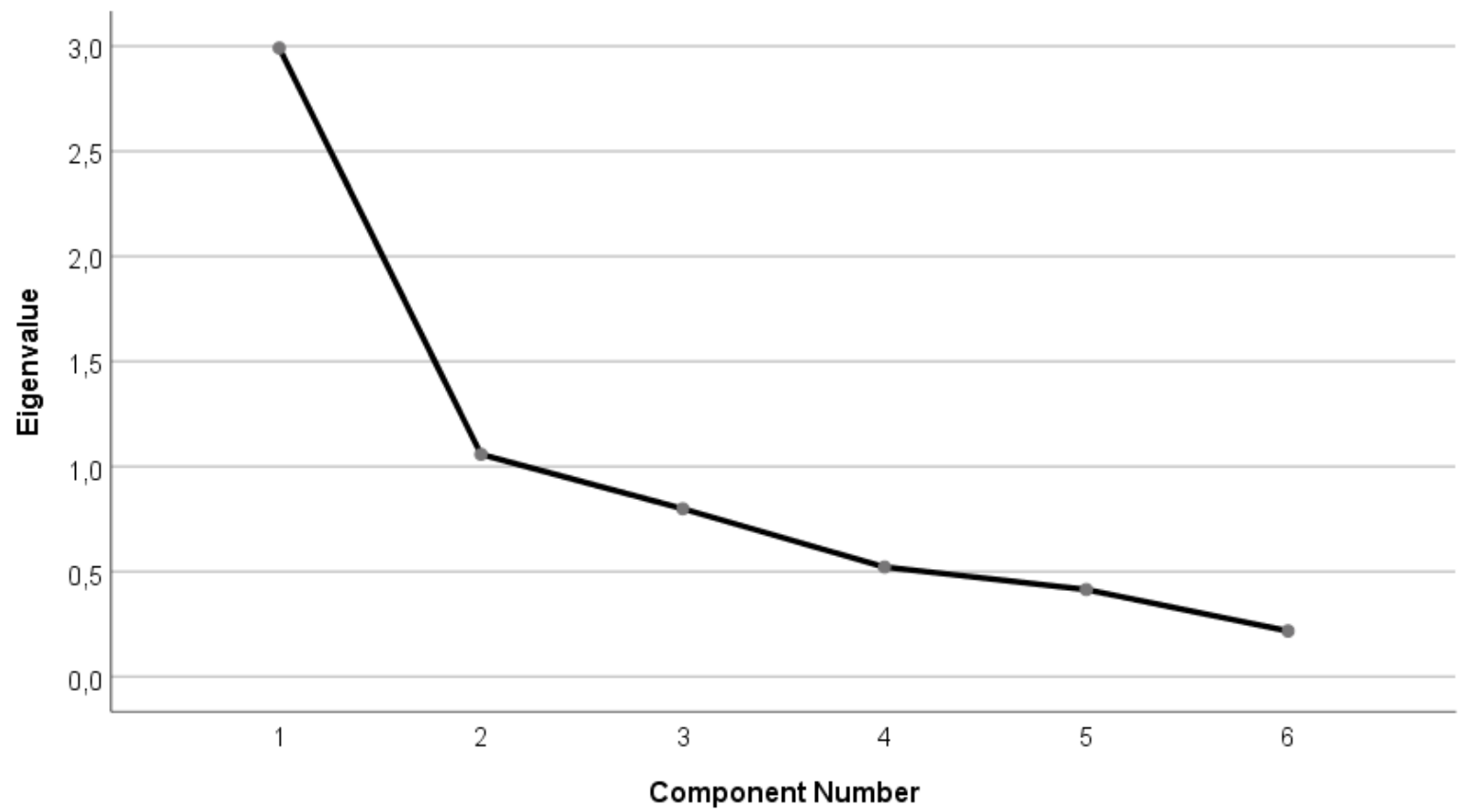

Graph 6. Factor analysis line graph of the items created for the practicum school belonging to the expectation scale (Eigen Value 1.596) 


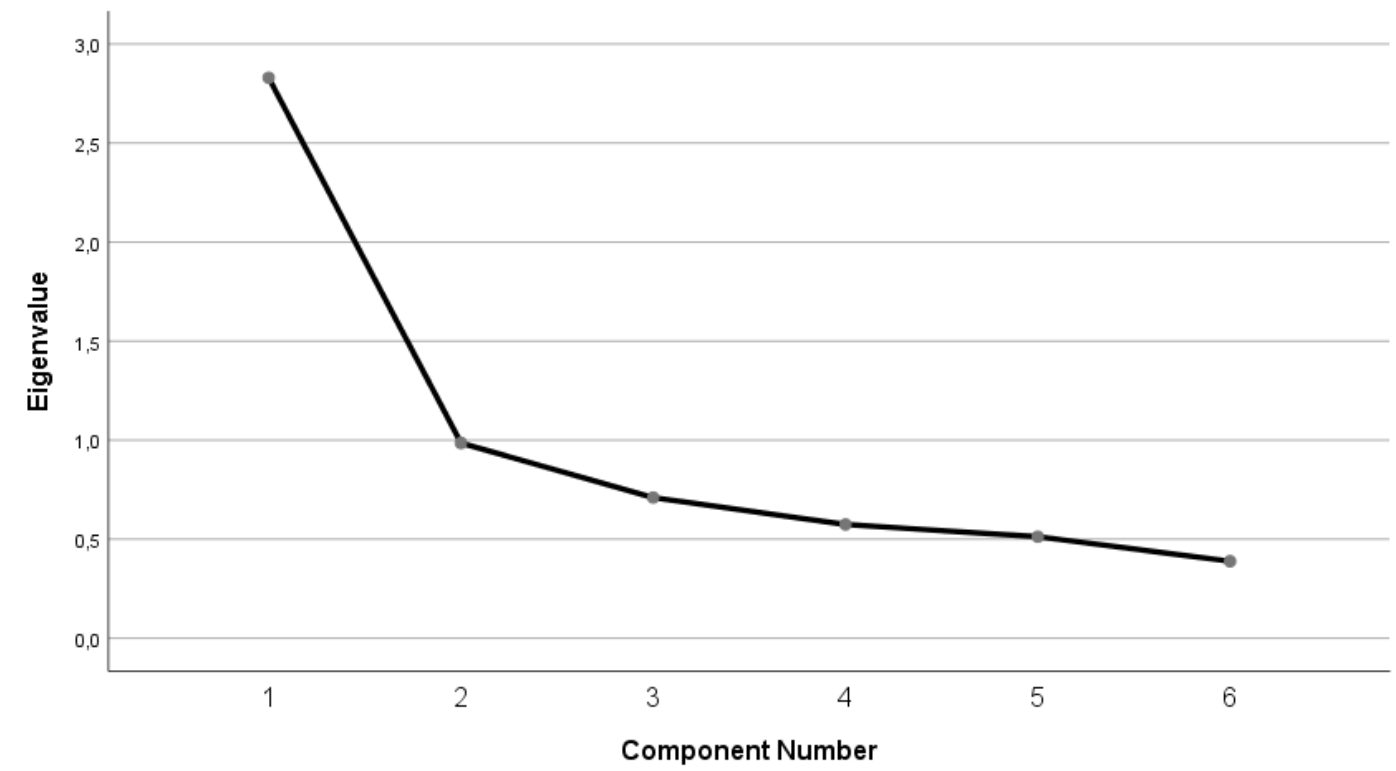

Graph 7. Factor analysis line graph of the items created for the teaching practicum belonging to the expectation scale (Eigen Values 2.991, 1.058)

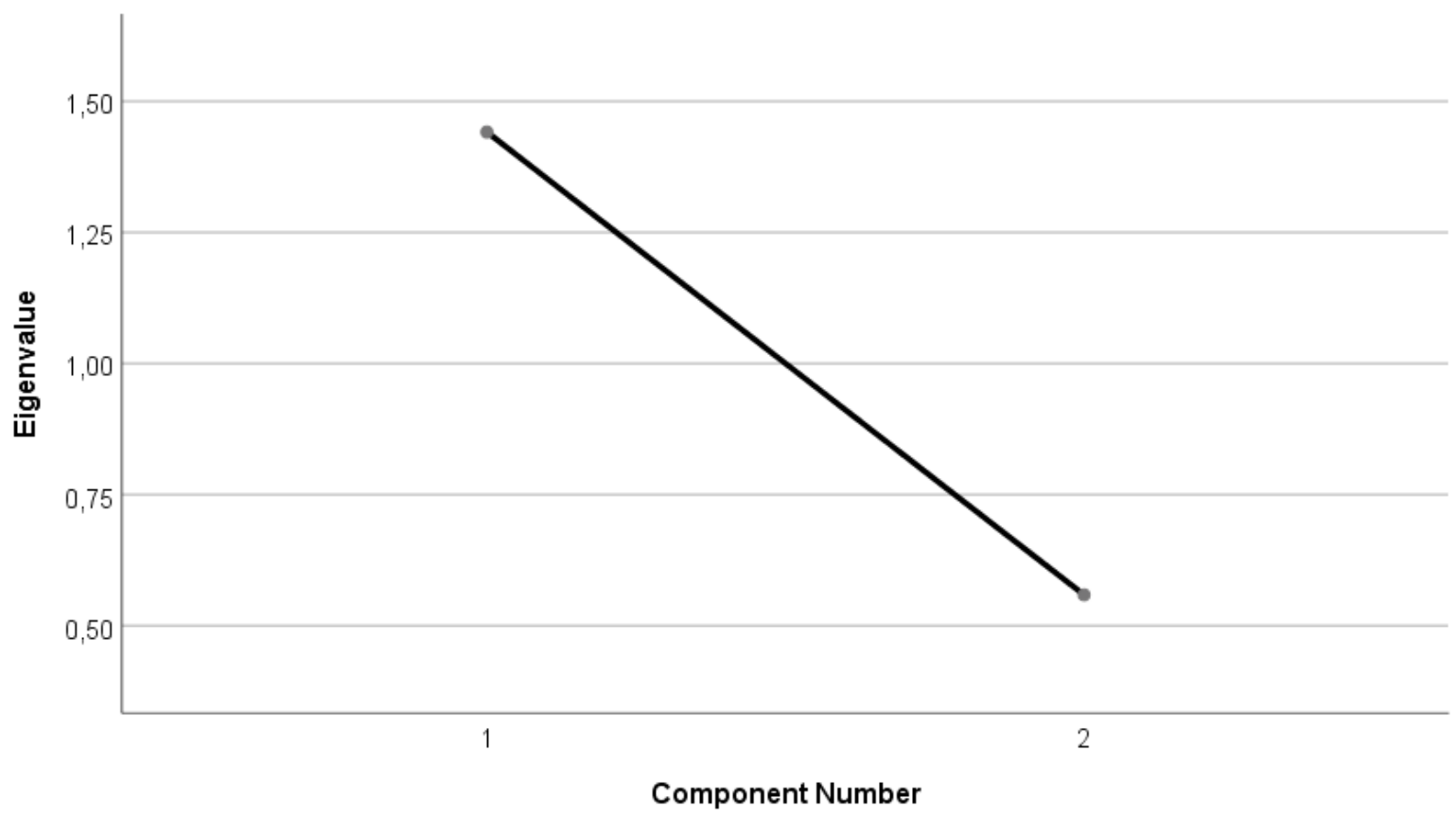

Graph 8. Factor analysis line graph of the items created for the other stakeholders belonging to the expectation scale (Eigen Value 1.441) 


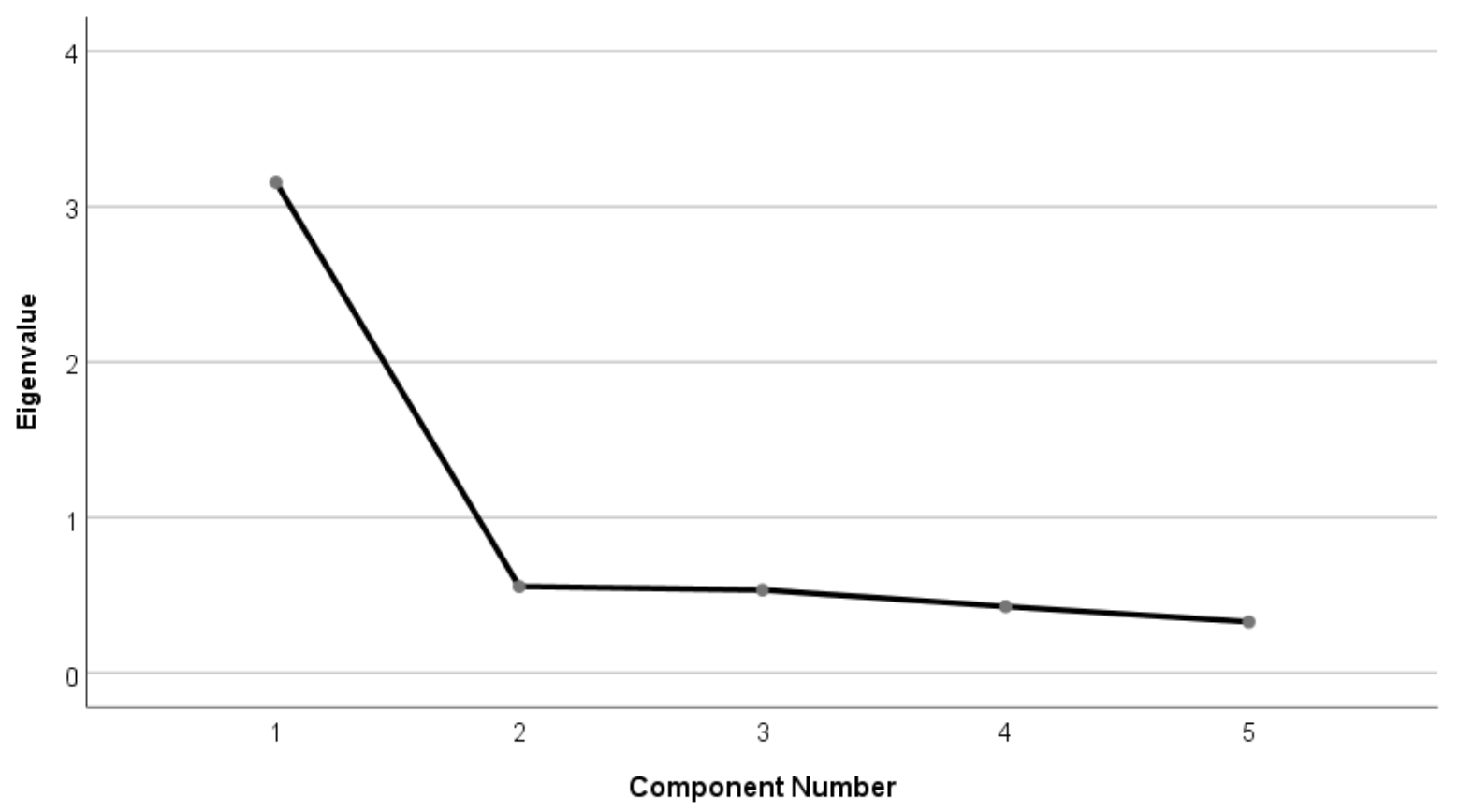

Graph 9. Factor analysis line graph of the items created for the attitudes at the end the teaching practicum as teacher candidate belonging to the reaction scale (Eigen Value 3.156)

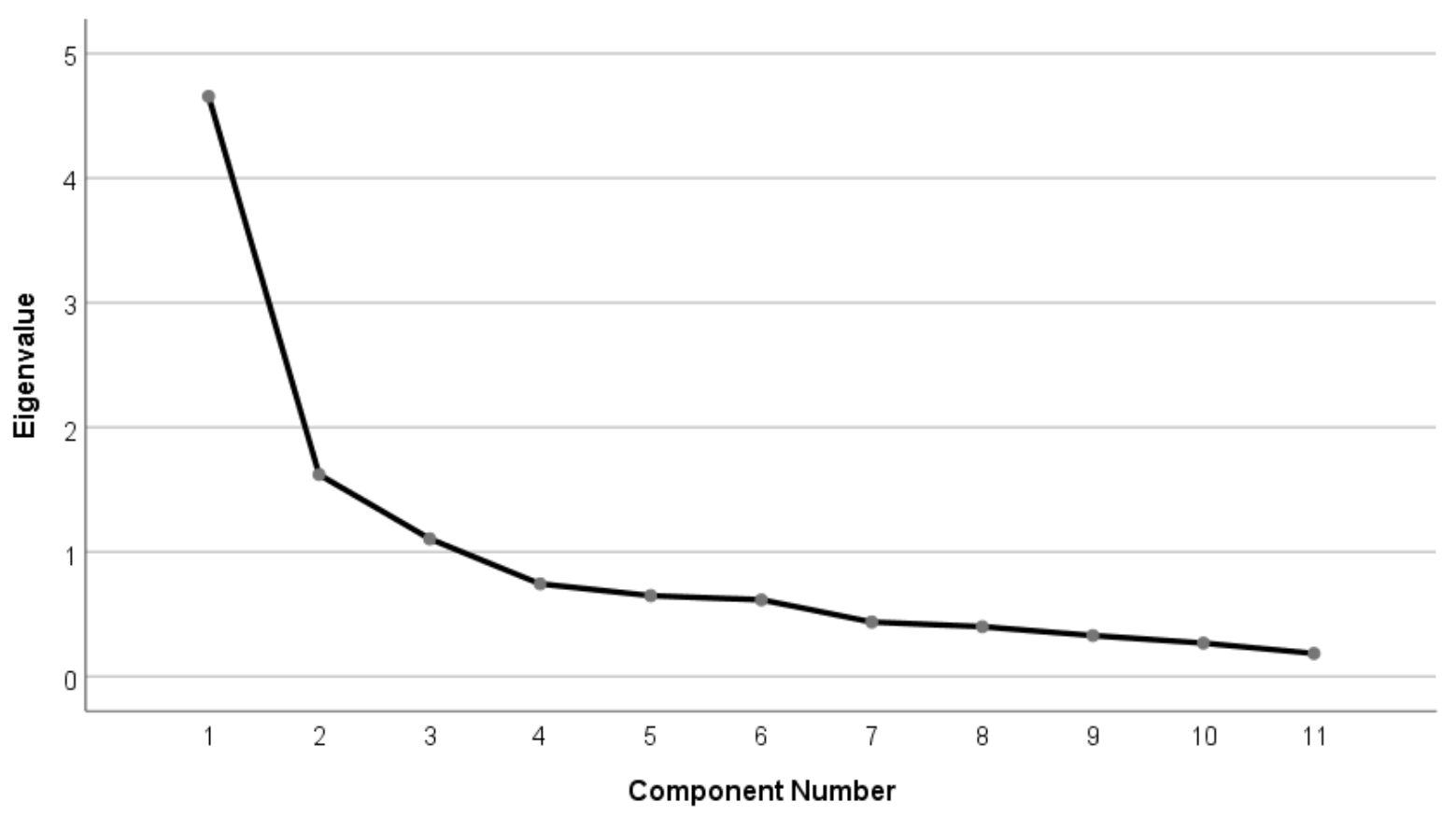

Graph 10. Factor analysis line graph of the items created for the attitudes in relation the teaching practicum belonging to the reaction scale (Eigen Values 5.656, 1.620, 1.105) 


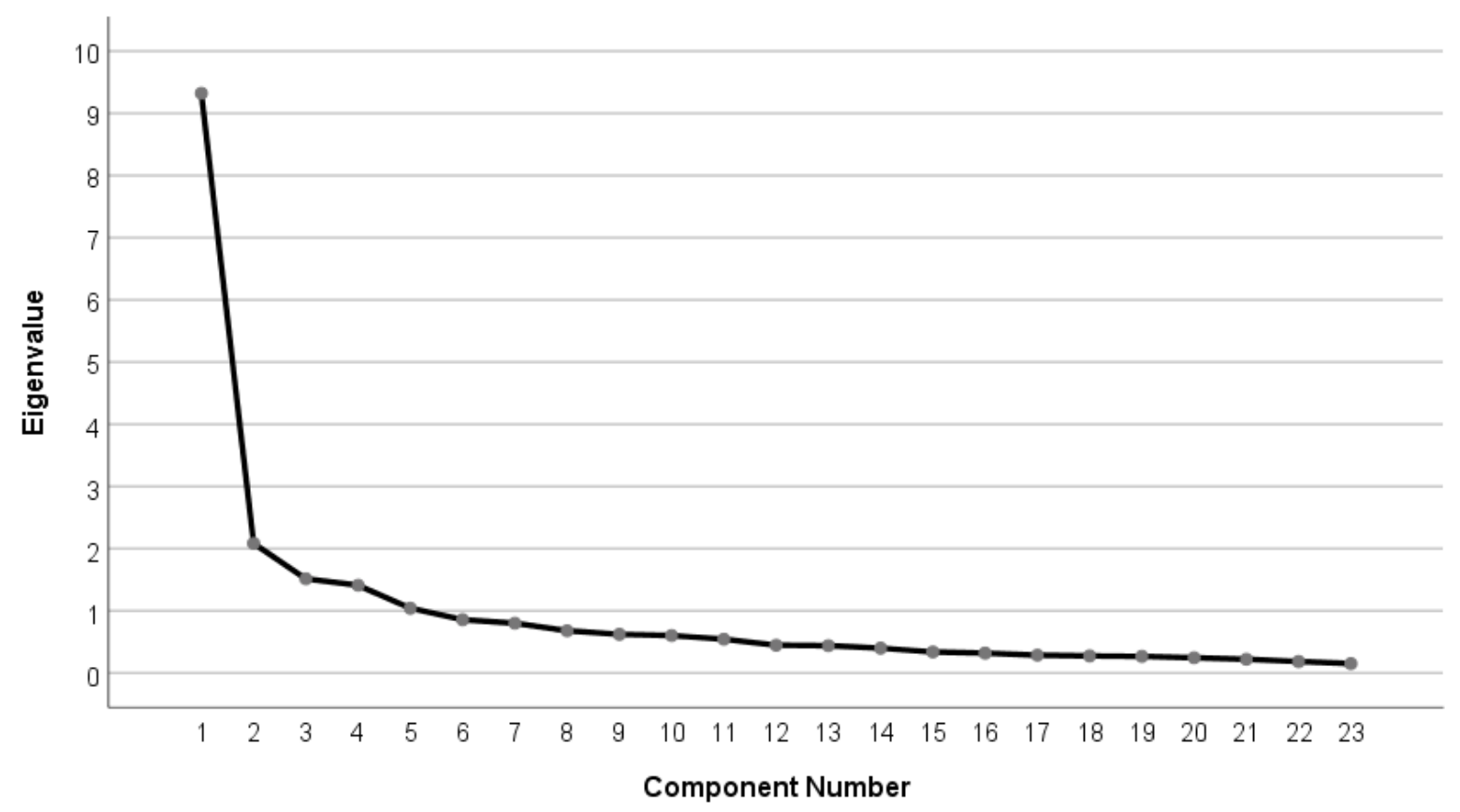

Graph 11. Factor analysis line graph of the items created for pre-service teachers' reactions about teaching practicum belonging to the reaction scale (Eigen Values 9.322, 2.083, 1.512, 1.408)

\section{Hizmet öncesi İngilizce öğretmenlerinin öğretmenlik uygulamasının değerlendirilmesi: ölçek geliştirme çalışması}

\section{$\ddot{O} \mathbf{z}$}

Bu çalışmanın amacı, İngilizce öğretmen adaylarının öğretim uygulamasına ilişkin beklentileri ve tutumlarına ışık tutmak için öğretim uygulamasını değerlendiren bir ölçme aracı geliştirmektir. Bu bağlamda iki ölçüm aracı; beklenti ölçeği ve reaksiyon ölçeği Kirkpatrick Eğitim Değerlendirme Teorisi (2000) ve EPOSTL (2007) 'nin birleşimine göre hazırlanmıştır. Bu çalışma, öğretmen adaylarının mevcut model hakkındaki görüşlerini ve mevcut uygulamadaki açıkları telafi etmek için neler yapılabileceğini belirlemek amacıyla Türkiye'de uygulanan mevcut uygulamalı programın genel bir eleştirel analizini yapmak amacıyla yapılmıştır. Çalışma kapsamında geçerlilik ve güvenilirlik çalışmaları yapılmıştır. Araştırma geçerliliği için; 2018-2019 bahar öğretim yılında üst düzey ELT öğrencilerinin bulunduğu bir devlet üniversitesinde pilot çalışma yapılımıştır. Pilot çalışma sonucunda madde yazma ve madde toplama aşamaları tamamlanmıştır. Yüz geçerliliğini, içerik geçerliliğini ve yapı geçerliliğini değerlendirmemek için alandan üç akademisyenden uzman görüşü alınmıştır. Türkiye'deki çeşitli üniversiteler çevresinde 2019-2020 güz döneminde Okul Deneyimi dersini alan 294 üst düzey ELT öğrencisi ile Açımlayıcı Faktör Analizi (EFA) ve Doğrulayıcı Faktör Analizi (DFA) yapılmıştır. Çalışma grupları maksimum çeşitlilik örnekleme yöntemine göre belirlenmiştir. Uygulamalar ve analizler doğrultusunda ölçeklerin geçerli, güvenilir ve 
psikometri açısından yeterli değerlere sahip olduğu söylenebilir. Cronbach Alpha katsayıları beklenti ve tutum ölçekleri için sırasıyla .96 ve .98 olarak hesaplanmıştır.

Anahtar sözcükler: öğretmenlik uygulaması; hizmet öncesi öğretmen eğitimi; program değerlendirme; ölçek geliştirme

\section{AUTHOR BIODATA}

Ilknur Kazaz currently works at Karadeniz Technical University as a lecturer. She holds an MA degree in Teaching English as a Foreign Language at Bilkent University. She pursues her doctoral study at Hacettepe University ELT Department and does research in Educational Assessment, Computational Linguistics, and Teacher Training.

Dr. Nuray Alagözlü works as a Professor of Linguistics in the Faculty of Education at Hacettepe University. She holds an MA degree in Teaching English as a Foreign Language at Bilkent University and a doctoral degree in Linguistics at Hacettepe University, Ankara. Her research interests are society, language education and language teacher education. 